NBER WORKING PAPER SERIES

THE EFFECT OF MONETARY POLICY ON REAL COMMODITY PRICES

\author{
Jeffrey A. Frankel \\ Working Paper 12713 \\ http://www.nber.org/papers/w12713 \\ NATIONAL BUREAU OF ECONOMIC RESEARCH \\ 1050 Massachusetts Avenue \\ Cambridge, MA 02138 \\ December 2006
}

The author would like to thank Ellis Connolly and Yun Jung Kim for exceptionally capable research assistance, and to thank for comments John Campbell, Pravin Chandrasekaran, Gunes Asik, and Lars Svensson. The views expressed herein are those of the author(s) and do not necessarily reflect the views of the National Bureau of Economic Research.

(C) 2006 by Jeffrey A. Frankel. All rights reserved. Short sections of text, not to exceed two paragraphs, may be quoted without explicit permission provided that full credit, including $\odot$ notice, is given to the source. 
The Effect of Monetary Policy on Real Commodity Prices

Jeffrey A. Frankel

NBER Working Paper No. 12713

December 2006

JEL No. E4,E5,F3,Q0

\begin{abstract}
$\underline{\text { ABSTRACT }}$
Commodity prices are back. This paper looks at connections between monetary policy, and agricultural and mineral commodities. We begin with the monetary influences on commodity prices, first for a large country such as the United States, then smaller countries. The claim is that low real interest rates lead to high real commodity prices. The theory is an analogy with Dornbusch overshooting. The relationship between real interest rates and real commodity prices is also supported empirically. One channel through which this effect is accomplished is a negative effect of interest rates on the desire to carry commodity inventories. The paper concludes with a consideration of implications for monetary policy.
\end{abstract}

Jeffrey A. Frankel

Kennedy School of Government

Harvard University

79 JFK Street

Cambridge, MA 02138

and NBER

jeffrey_frankel@harvard.edu 


\section{The Effect of Monetary Policy on Real Commodity Prices}

\section{Introduction}

Commodity prices are back, with a vengeance.

In the 1970s, macroeconomic discussions were dominated by the oil price shocks and other rises in agricultural and mineral products that were thought to play a big role in the stagflation of that decade. ${ }^{1}$ In the early 1980s, any discussion of alternative monetary regimes was not complete without a consideration of the gold standard and proposals for other commodity-based standards.

Yet the topic of commodity prices fell out of favor in the late 1980s and the 1990s. Commodity prices generally declined during that period; perhaps declining commodity prices are not considered as interesting as rising prices. Nobody seemed to notice how many of the victims of emerging market crises in the 1990s were oil producers that were suffering, among other things, from low oil prices (Mexico, Indonesia, Russia) or others suffering from low agricultural prices (Brazil and Argentina). The favorable effect of low commodity prices on macroeconomic performance -- helping deliver lower inflation in the US in the 1990s than had been thought possible at such high rates of growth and employment -- was occasionally remarked. But it was not usually described as a favorable supply shock, the mirror image of the adverse supply shocks of the 1970s. It always received far less attention than the influence of other factors, such as the declining prices of semi-conductors and other information technology and communication equipment. Indeed, anyone who talked about sectors where the product was clunky and mundane as copper, crude petroleum and soy beans was considered behind the times. In Alan Greenspan's phrase, GDP had gotten "lighter." Agriculture and mining no longer constituted a large share of the New Economy, and did not matter much in an age dominated by ethereal digital communication, evanescent dotcoms, and externally outsourced services.

Now oil prices and many broader indices of commodity prices are again at or near all-time highs in nominal terms, and are very high in real terms as well. Copper, platinum, nickel, zinc and lead, for example, all hit record highs in 2006, in addition to crude oil. As a result, commodities are once again hot. It turns out that mankind has to live in the physical world after all ! Still, the initial reaction in 2003-04 was relaxed, on several grounds: (1) Oil was no longer a large share of the economy, it was said; (2) Futures markets showed that the "spike" in prices was expected to be only temporary; and (3) Monetary policy need focus only on the core CPI inflation rate and can safely ignore the volatile food and energy component, unless or until it starts to get passed through into the core rate. But by 2005-2006, the increase in prices had gone far

\footnotetext{
${ }^{1}$ A small dissenting minority viewed the increases in prices of oil and other commodities in the 1970s as the result of overly expansionary US monetary policy, rather than as an exogenous inflationary supply shock (the result of the 1973 Arab oil embargo and the 1979 fall of the Shah of Iran). After all, was it just a coincidence that other commodity prices had gone up at the same time, or in the case of agricultural products, had actually preceded the oil shocks?
} 
enough to receive much more serious attention. This was especially true with regard to the perceived permanence of oil prices, largely because the futures price had gone from implying that the rise in the spot price was mostly temporary to implying that is mostly permanent.

Certain lessons of the past are well-remembered, such as the dangers of the Dutch Disease for countries undergoing a commodity export boom. But others have been forgotten, or were never properly absorbed.

With regard to point (3), it is time to examine more carefully the claim that if an increase in energy or agricultural prices does not appear in the core CPI, then monetary policy can ignore it. The central argument of this paper is that high real commodity prices can be a signal that monetary policy is loose. Thus they can be a useful monetary indicator (among many others). The analysis is both theoretical and empirical. The empirical work includes the determination of real commodity prices in the United States, the determination of prices in other smaller countries, and the determination of inventories. We find that real interest rates are an important determinant of the demand for inventories and in turn of the prices of agricultural and mineral commodities.

The current fashion in monetary policy is inflation-targeting, by which is standardly meant targeting the CPI. ${ }^{2}$ To be sure, the usual emphasis is on the core inflation rate "excluding the volatile food and energy sector." The leadership of the Federal Reserve has indicated that the appropriate response to the oil-shock component of recent inflation upticks is to ignore it, i.e., accommodate it. But just because agricultural and mineral product prices are volatile, does not mean that there is no useful information in them. The prices of gold and other minerals used to be considered useful leading indicators of inflationary expectations, precisely because they moved faster than the sluggish prices of manufactured goods and services. Nor does the volatility mean that excluding such products from the price index that guides monetary policy is necessarily appropriate.

In the first place, the "core CPI" is not a concept that is especially well understood among the general population. Thus the public will not necessarily be reassured when the central bank tells them not to worry about big increases in food and energy prices. Attempts to explain away high numbers for headline inflation make it sound like the authorities are granting themselves an ad hoc self-pardon - like a "dog ate my homework" excuse. This can undermine the public credibility of the central bank; but credibility and transparency is the whole point of announcing an observable target in the first place. Thus targeting the core CPI may not buy as much credibility as targeting something more easily understood (even if with a wider band).

The many proponents of inflation targeting will argue that the regime, if properly instituted, makes clear from the beginning that it excludes volatile commodity prices, so that there is no loss in credibility. But, in the second place, let us ask is it appropriate for the inflation target to exclude commodity prices. They may be important, on terms of trade grounds, especially in smaller countries. Stabilizing the traded goods sector is itself an important goal in a world where balance of payments deficits can lead to

\footnotetext{
${ }^{2}$ Among many other references: Bernanke, et al (1999), Svensson (1995, 1999), and Truman (2003).
} 
financial crises, in which the previously declared currency regime is often one among many subsequent casualties. Recent oil price increases have also illustrated the necessity to take into account terms of trade shocks that come on the import side as well as the export side. Does there exist a price index to serve as intermediate target that is more easily understood by the public than the core CPI, but also more robust with respect to terms of trade shocks than the overall CPI? Candidates include a producer price index and an export price index.

It is a tenet of international economics textbooks that a desirable property of a currency regime is that the exchange rate be allowed to vary with terms of trade shocks: that the currency automatically depreciates when world prices of the import commodity go up (say, oil for the US or Switzerland, or wheat for Japan or Saudi Arabia), and that it automatically depreciates when world prices of the export commodity go down (say oil for Saudi Arabia and wheat for Canada). Yet CPI targeting does not have this property. To keep the headline inflation rate constant one must respond to a rise on world markets in the dollar price of imported oil by tightening monetary policy and appreciating the currency against the dollar enough to prevent the domestic price of the importable from rising. This response is the opposite from accommodating the adverse terms of trade shock, which would require a depreciation. It is true that the core inflation rate does not share this unfortunate property with the headline rate (unless the price increase comes in non-energy commodities like semi-conductors that are in the core). But the other half of terms of trade shocks are declines on world markets in the price of a country's export commodity. Theory says that when the dollar price of oil goes down, Saudi Arabia or Norway ought to depreciate against the dollar. But inflation targeting - either the headline CPI variety or the core CPI variety -- does not allow this result. One would need to target a price index that specifically featured prominently the price of the exportable. The fundamental difficulty is that excluding the volatile food and energy components is not sufficient to accommodate the terms of trade, either if some imports lie outside those two sectors or if some exports lie within those two sectors.

Throughout this paper we will adopt the familiar assumption that all goods can be divided into homogeneous agricultural and mineral commodities, on the one hand, and differentiated manufactured goods and services on the other hand, and that the key distinction is that prices of the former are perfectly flexible, so that their markets always clear, and that prices of the latter are sticky in the short run, so that their markets do not. ${ }^{3}$ The plan is to look at connections between commodities and monetary policy. We begin with the monetary influences on commodity prices -- first for a large country, then a small one. We conclude with a viewpoint based on reverse causality: the possible influence of commodity prices on monetary policy in a consideration of what price index to use for the nominal anchor. Even if one is wedded to, say, a Taylor rule, the question of what price index to use merits discussion. The author summarizes a proposal made elsewhere, for countries with volatile terms of trade, to use an export price index (or producer price index) in place of the CPI. If one is enamored of a simpler pricetargeting regime, then the proposal is to Peg the Export Price Index (PEPI) in place of targeting the CPI.

\footnotetext{
${ }^{3}$ For young readers, I will recall that these distinctions were originally due to Arthur Okun (1975), who called the two sectors auction goods vs. customer goods.
} 


\section{The Effect of Monetary Policy on Real Commodity Prices}

The central purpose of this paper is to assert the claim that monetary policy, as reflected in real interest rates, is an important -- and usually under-appreciated -determinant of the real prices of oil and other mineral and agricultural products, while far from the only determinant.

\section{Effect of US short-term real interest rates on real US commodity prices}

The argument can be stated in an intuitive way that might appeal to practitioners, as follows. High interest rates reduce the demand for storable commodities, or increase the supply, through a variety of channels:

- by increasing the incentive for extraction today rather than tomorrow (think of the rates at which oil is pumped, zinc is mined, forests logged, or livestock herds culled)

- by decreasing firms' desire to carry inventories (think of oil inventories held in tanks)

- by encouraging speculators to shift out of commodity contracts (especially spot contracts), and into treasury bills.

All three mechanisms work to reduce the market price of commodities, as happened when real interest rates were high in the early 1980s. A decrease in real interest rates has the opposite effect, lowering the cost of carrying inventories, and raising commodity prices, as happened during 2002-2004. Call it part of the "carry trade."

\section{a. Theory: The overshooting model}

The theoretical model can be summarized as follows. A monetary contraction temporarily raises the real interest rate, whether via a rise in the nominal interest rate, a fall in expected inflation, or both. Real commodity prices fall. How far? Until commodities are widely considered "undervalued" -- so undervalued that there is an expectation of future appreciation (together with other advantages of holding inventories, namely the "convenience yield") that is sufficient to offset the higher interest rate (and other costs of carrying inventories: storage costs plus any risk premium). Only then, when expected returns are in balance, are firms willing to hold the inventories despite the high carrying cost. In the long run, the general price level adjusts to the change in the money supply. As a result, the real money supply, real interest rate, and real commodity price eventually return to where they were.

\footnotetext{
${ }^{4}$ Frankel, "Why Are Oil and Metal Prices High? Don't Forget Low Interest Rates," (published as "Real Interest Rates Cast a Shadow Over Oil"), Financial Times, April 15, 2005.
} 
The theory is the same as Rudiger Dornbusch's (1976) famous theory of exchange rate overshooting, with the price of commodities substituted for the price of foreign exchange -- and with convenience yield substituted for the foreign interest rate. The deep reason for the overshooting phenomenon is that prices for agricultural and mineral products adjust rapidly, while most other prices adjust slowly. ${ }^{5}$

The theory can be reduced to its simplest algebraic essence as a claimed relationship between the real interest rate and the spot price of a commodity relative to its expected long-run equilibrium price. This relationship can be derived from two simple assumptions. The first one governs expectations. Let

$s \equiv$ the spot price,

$\bar{s} \equiv$ its long run equilibrium,

$p \equiv$ the economy-wide price index,

$q \equiv s-p$, the real price of the commodity, and

$\bar{q} \equiv$ the long run equilibrium real price of the commodity,

all in log form. Market participants who observe the real price of the commodity today lying above or below its perceived long-run value, expect it in the future to regress back to equilibrium over time, at an annual rate that is proportionate to the gap:

$$
E[\Delta(s-p)] \equiv E[\Delta q]=-\theta(q-\bar{q})
$$

Or

$$
E(\Delta s)=-\theta(q-\bar{q})+E(\Delta p)
$$

Following the classic Dornbusch overshooting paper, we begin by simply asserting the reasonableness of the form of expectations in these equations: a tendency to regress back toward long run equilibrium. But, as in that paper, it can be shown that regressive expectations are also rational expectations, under certain assumptions regarding the stickiness of other goods prices (manufactures and services) and certain restrictions on parameter values. ${ }^{6}$

The second equation concerns the decision whether to hold the commodity for another period - either leaving it in the ground or on the trees or holding it in inventories - or to sell it at today's price and deposit the proceeds in the bank to earn interest. The

\footnotetext{
${ }^{5}$ Frankel (1984).

${ }^{6}$ Frankel (1986).
} 
arbitrage condition is that the expected rate of return to these two alternative courses of action must be the same: $\quad E \Delta s+c=i$,

where

$c \equiv c y-s c-r p$

$c y \equiv$ convenience yield from holding the stock (e.g., the insurance value of having an assured supply of some critical input in the event of a disruption, or in the case of gold the psychic pleasure component of holding it)

$s c \equiv$ storage costs (e.g., costs of security to prevent plundering by others, rental rate on oil tanks or oil tankers, etc.),

$r p \equiv$ risk premium, which is positive if being long in commodities is risky, and

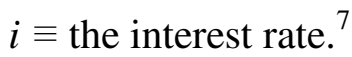

There is no reason why the convenience yield, storage costs, or risk premium should be constant over time. If one is interested in the derivatives markets, the forward discount or slope of the futures curve, $f-s$ in log terms, is given by:

$$
f-s=i-c y+s c, \text { or equivalently by } E \Delta s-r p .
$$

Parenthetically, the introduction to this paper noted that conventional wisdom initially regarded the 2003-04 "spike" in oil prices as only temporary, but expectations regarding the long-run oil price were subsequently revised sharply upward. The changes in the perceived transience or permanence of the price increase were standardly based on the futures markets, which did not catch up with the increase in the spot price until after a year or so. It is curious that so many economists and central bankers are ready to accept that the futures price of oil is an unbiased forecast of the future spot price. This proposition of course would follow from the two propositions that the futures price is an accurate measure of expectations (no risk premium) and that expectations are rational. Both halves of the joint hypothesis are open to question. Few familiar with the statistics of forward exchange rates claim that they are an unbiased predictor of the future spot exchange rate. Few familiar with the statistics of the interest rate term structure claim that the long-term interest rate contains an unbiased predictor of future short term interest rates. Why, then, expect the oil futures price to be an unbiased predictor of the future spot price? ${ }^{8}$ The convenience yield, storage costs, and risk premium are variable. So

\footnotetext{
7 Working (1949) and Breeden (1980) are classic references on the roles of carrying costs and the risk premium, respectively, in commodity markets. Yang, Bessler and Leatham (2001) review the literature.

8 Studies of bias in the commodities futures price as a predictor of the spot price include Bessembinder (1992), Brenner and Kroner (1995), Covey and Bessler (1995), Dusak (1973), Fama and French (1987), Fortenbery and Zapata (1997), and Kolb (1992). Most assume that investors' expectations must be
} 
the backwardation (forward prices below spot) in oil prices in 2004 was not necessarily a reason to be complacent, and the flattening or contango (forward prices above spot) in 2005-06 was not necessarily a reason to worry.

Nevertheless, the large increase in the slope of the futures yield curve during the period 2004-06, the same period that the Federal Reserve was steadily raising interest rates, is consistent with the theory that we have just developed: that the slope depends on the interest rate plus storage costs minus convenience yield. Harder to explain is that the move to contango came rather sharply, however, in early April 2005, rather than gradually. Here a rapid revision in expectations may have played a role.

To get our main result, we simply combine equations (2) and (3):

$$
\begin{aligned}
& -\theta(q-\bar{q})+E(\Delta p)+c=i \quad=> \\
& q-\bar{q}=-(1 / \theta)(i-E(\Delta p)-\mathrm{c}) .
\end{aligned}
$$

Equation (5) says that the real price of the commodity (measured relative to its long-run equilibrium) is inversely proportional to the real interest rate (measured relative to a constant term that depends on convenience yield). When the real interest rate is high, as in the 1980s, money flows out of commodities, just as it flows out of foreign currencies, emerging markets, and other securities. Only when the prices of these alternative assets are perceived to lie sufficiently below their future equilibria will the arbitrage condition be met. Conversely, when the real interest rate is low, as in 2001-05, money flows into commodities, just as it flows into foreign currencies, emerging markets, and other securities. Only when the prices of these alternative assets are perceived to lie sufficiently above their future equilibria will the arbitrage condition be met.

\section{b. The simplest test}

One can imagine a number of ways of testing the theory.

One way of isolating the macroeconomic effects on commodity prices is to look at jumps in financial markets that occur in immediate response to government announcements that change perceptions of monetary policy, as was true of Fed money supply announcements in the early 1980s. Money announcements that caused interest rates to jump up would on average cause commodity prices to fall, and vice versa. The experiment is interesting, because news regarding supply disruptions and so forth is unlikely to have come out during the short time intervals in question. ${ }^{9}$

unbiased in-sample, and infer a time-varying risk premium. The exception, Choe (1990), infers expectations from survey data.

${ }^{9}$ Frankel and Hardouvelis (1985). 
The relationship between the real commodity price and the real interest rate, equation (5), can also be tested more directly, because variables can be measured fairly easily. ${ }^{10}$ This is the test we pursue here.

We begin with a look at some plots. Three major price indices that have been available since 1950 -- from Dow Jones, Commodity Resources Board, and Moody's -are used in the first three figures. (In addition two others, which started later than 1950, are illustrated in an Appendix I ). To compute the real commodity price we take the log of the commodity price index minus the log of the CPI. To compute the real interest rate, we take the one-year interest rate and subtract off the one year inflation rate observed over the preceding year.

The negative relationship predicted by the theory seems to hold. We next apply OLS regression to these data.

It would not be reasonable to expect the regression relationship to hold precisely in practice. It would be foolish to think that the equation captures everything. In reality, a lot of other things beyond real interest rates influence commodity prices. There are bound to be fluctuations both in $\bar{q}$, the long-run equilibrium real price, and $c$, which includes convenience yield, storage costs, and risk premium. These fluctuations are not readily measurable. ${ }^{11}$ Such factors as weather, political vicissitudes in producing countries, and so forth, are likely to be very important when looking at individual commodities. Indeed analysts of oil or coffee or copper pay rather little attention to macroeconomic influences, and instead spend their time looking at microeconomic determinants. Oil prices have been high in 2004-06 in large part due to booming demand from China and feared supply disruptions in the Middle East, Russia, Nigeria and Venezuela. There may now be a premium built in to the convenience yield arising from the possibilities of supply disruption related to terrorism, uncertainty in the Persian Gulf, and related risks. Yet another factor concerns the proposition that the world supply of oil may be peaking in this decade, as new discoveries lag behind consumption (Hubbert's Peak $^{12}$ ). This would imply that $\bar{q}$, the world long run equilibrium real price of oil has shifted upward. Other factors apply to other commodities. In coffee, the large-scale entry of Vietnam into the market lowered prices sharply a few years ago. Corn, sugar, and cotton are heavily influenced by protectionist measures and subsidies in many countries. And so on.

\footnotetext{
${ }^{10}$ One precedent: Barsky and Summers (1988, Part III) established an inverse relationship between the real interest rate and the real prices of gold and nonferrous metals.

${ }^{11}$ An extension for future research would be to attempt to control for some influences on $c$ by means of measures of economic activity and risk such as those used in the inventories equation in the next section.

${ }^{12}$ Deffeyes (2005). Notwithstanding that such predictions have in the past been proven wrong.
} 
Figure 1: US Real Commodity Prices and Real Interest Rates

Figure 1a

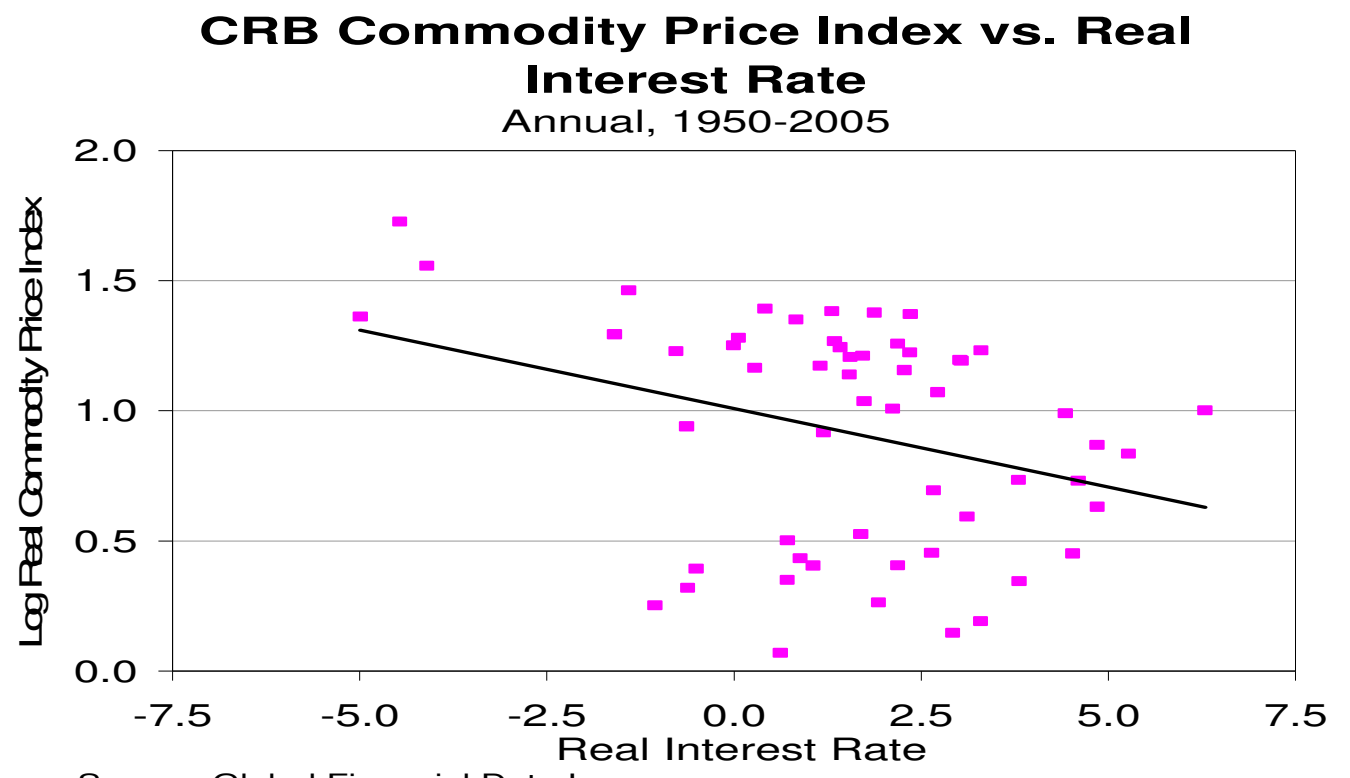

Source: Global Financial Data Inc.

Figure 1b 


\section{Dow Jones Commodity Price Index vs. Real Interest Rate}

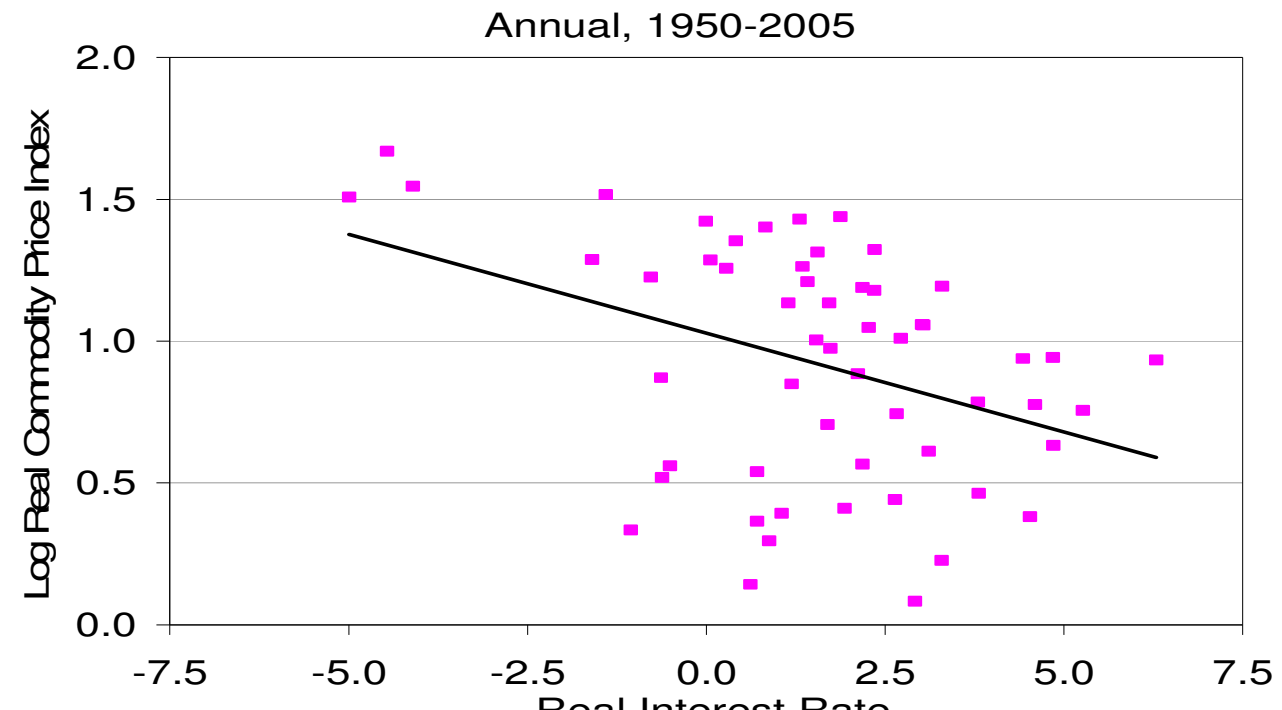

Source: Global Financial Data Inc.

Figure 1c

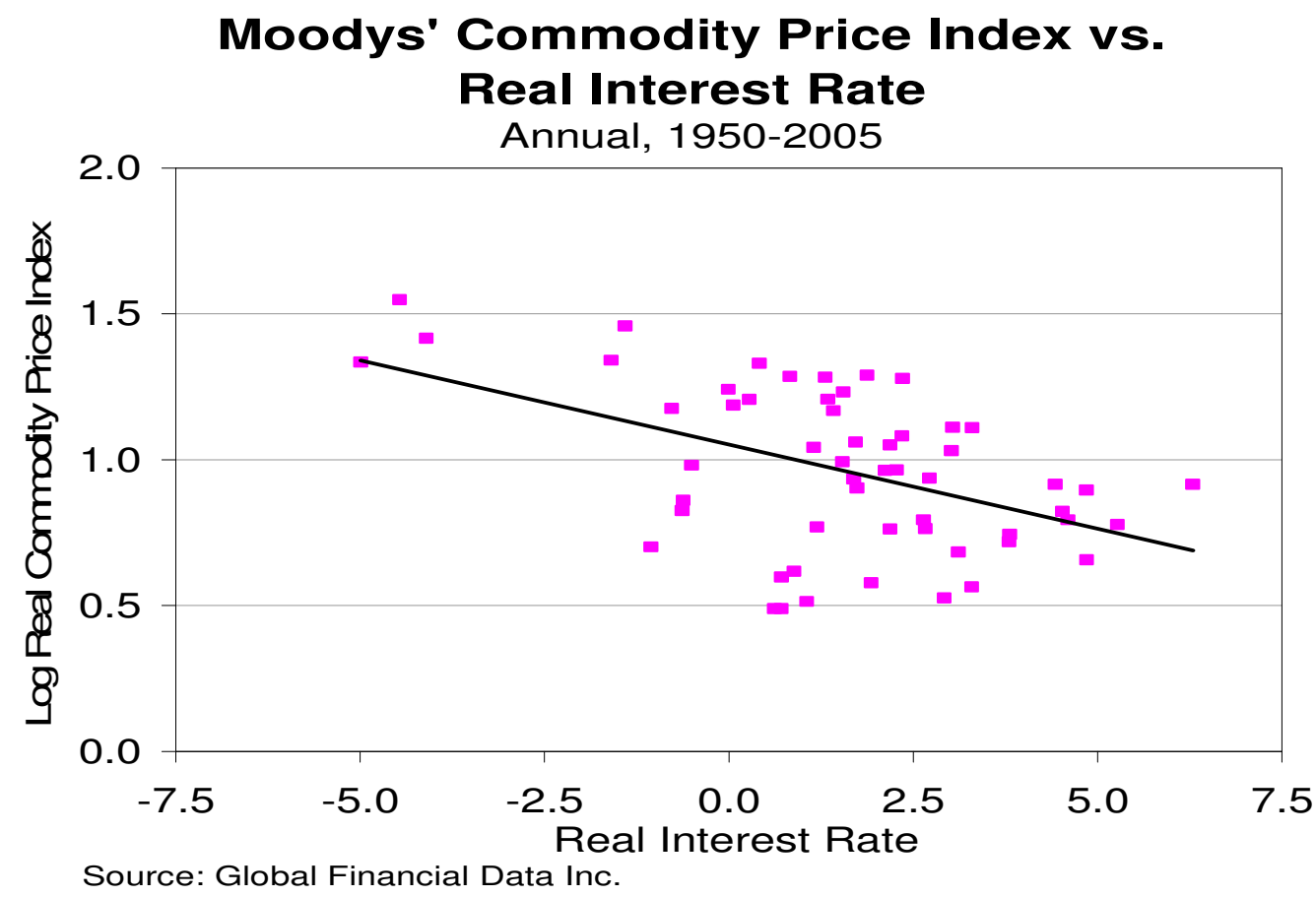

Such effects in individual commodities partially average out when looking at a basket average of commodity prices. This is one reason to use aggregate indices in the 
tests reported below.

Table 1 reports regressions of real commodity prices over the period 1950-2005. The results are statistically significant at the $5 \%$ level for all three of the major price indices that have been available since 1950 -- from Dow Jones, Commodity Resources Board (CRB), and Moody's - and significant for one of the two with a shorter history (Goldman Sachs). All are of the hypothesized negative sign. The estimated coefficient for the CRB, -.06, is typical. It suggests that when the real interest rate goes up 1 percentage point (100 basis points), it lowers the real commodity price by .06 , i.e. 6 per cent. It also suggests that the estimate for $1 / \theta=6$, so $\theta=.16$. In other words, the expected speed of adjustment per year is estimated at $16 \%$. The expected half-life is about 4 years $(.84$ to the 4 th power $=.5)$.

The table also reports results for 23 individual commodities, presented in order of the size of the estimated coefficient. Despite our fears that sector-specific microeconomic factors swamp the macroeconomic influences for individual commodities, the coefficient is of the hypothesized sign in 19 out of 23 cases and is statistically significant in half (11 out of 23). Interestingly oil and gold are the worst of the 23, showing (insignificant) positive coefficients ! A fixed effects panel incorporates the information for all the individual commodities with the coefficient constrained to be the same. The coefficient is estimated at -.046 and is highly significant statistically.

The results in Table 1 suggest that the significant negative relationship between commodity prices and interest rates is reasonably robust across commodity price measures. Is the result is robust over time? It appears that the negative correlation is significant over 1950-1979 (Table 1a, reported in the appendix). However, since 1980, there does not appear to have been a stable relationship between log real commodity prices and the real interest rate (Table 1b). The same is true if the sample is divided at 1976 or 1982. 


\section{Table 1: Regression of log real commodity prices on real interest rates}

Over whole sample (1950-2005)

Results by commodity indices, individual commodities and fixed-effects panel of commodities.

\begin{tabular}{|c|c|c|c|}
\hline \multicolumn{4}{|c|}{$\begin{array}{l}\text { Log Real Commodity Prices and Interest Rates } \\
\text { sample: 1950-2005 (56 annual observations) } \\
\text { real interest rate in \% and real commodity prices in log units }\end{array}$} \\
\hline & Coefficient & Std error & sig. $5 \%$ \\
\hline Goldman Sachs (1969-) & -0.080 & 0.029 & * \\
\hline Dow Jones & -0.070 & 0.023 & * \\
\hline CRB & -0.060 & 0.024 & * \\
\hline Moodys & -0.058 & 0.014 & * \\
\hline Reuters (1959-) & -0.009 & 0.024 & \\
\hline \multicolumn{4}{|c|}{ COMMODITIES (by coefficient in ascending order) } \\
\hline Sugar & -0.144 & 0.035 & * \\
\hline Soy bean oil & -0.096 & 0.030 & * \\
\hline Corn & -0.091 & 0.032 & * \\
\hline Rubber & -0.090 & 0.037 & * \\
\hline Wheat & -0.088 & 0.033 & * \\
\hline Lead & -0.071 & 0.022 & * \\
\hline Oats & -0.066 & 0.029 & * \\
\hline Soy beans & -0.064 & 0.027 & * \\
\hline Cocoa & -0.063 & 0.035 & \\
\hline Cotton & -0.061 & 0.030 & * \\
\hline Zinc & -0.050 & 0.018 & * \\
\hline Cattle & -0.048 & 0.016 & * \\
\hline FIXED-EFFECTS PANEL & -0.046 & 0.006 & * \\
\hline Nickel & -0.032 & 0.018 & \\
\hline Hogs & -0.031 & 0.022 & \\
\hline Copper & -0.026 & 0.028 & \\
\hline Tin & -0.026 & 0.032 & \\
\hline Aluminium & -0.022 & 0.017 & \\
\hline Coffee & -0.015 & 0.038 & \\
\hline Palladium & -0.012 & 0.025 & \\
\hline Silver & 0.002 & 0.031 & \\
\hline Platinum & 0.003 & 0.014 & \\
\hline Oil & 0.009 & 0.028 & \\
\hline Gold & 0.025 & 0.032 & \\
\hline
\end{tabular}

\section{c. An Effect on Inventories?}

Since one of the hypothesized mechanisms of transmission from real interest rates to real commodity prices runs via the demand for inventories, it may be instructive to look at inventory data. Appendices 2 and 3 report regression results for oil inventories 
(Tables 4 and 5). The coefficient on the real interest rate is often negative, as hypothesized. It is not always statistically significant, until we control for three other standard determinants of inventory demand, as in Table 2 reported here. The three other determinants are:

- industrial production, representing the transactions demand for inventories. Higher economic activity should have a positive effect on the demand for inventory holdings.

- $\quad$ risk (political, financial, and economic) among a weighted average of 12 top oil producers. In our measure, a rise in the index represents a decrease in risk, which should have a negative effect on the demand for inventories.

- the spot-futures spread. Intuitively the futures-spot spread reflects the speculative return to holding inventories. ${ }^{13}$ A higher spot-futures spread, or lower future-spot spread, signifies a low speculative return and should have a negative effect on inventory demand.

More formally, equation (4) gives us the arbitrage condition relevant for firms deciding whether to incur storage costs:

$$
i-c y+s c=E \Delta s-r p
$$

We substitute in the arbitrage condition that comes from the financial speculators,

and solve for storage costs.

$$
f-s=E \Delta s-r p
$$

$$
s c=f-s+c y-i
$$

Storage costs rise with the extent to which inventory holdings strain existing storage capacity:

$$
S C=\Phi(\text { INVENTORIES }) .
$$

Invert the equation for the supply of inventory storage capacity, and set inventory demand equal to supply:

$$
\begin{aligned}
\text { INVENTORIES } & =\Phi^{-1}(s c) \\
& =\Phi^{-1}(c y-i-(s-f))
\end{aligned}
$$

We see from the equation that inventory holdings are positively related to convenience yield (which is in turn determined by industrial production and geopolitical risk), and negatively related to the interest rate and the spot-futures spread (two components of the opportunity cost of holding inventories).

13 E.g., see the discussion of Figure 1.22 in the World Economic Outlook April 2006, International Monetary Fund, Washington, DC. 
Equation (6) is a model of the stock of inventories that firms desire to hold. In practice the actual level of inventories generally deviates from the desired levels. For example, a sudden unexpected acceleration of industrial production, will in the short run show up as a fall in inventories held, even though the desired level of inventories goes up. Only over time are firms able to adjust their actual level of inventories in line with the desired level. This phenomenon is very well know, and was the origin of the "stock adjustment" specification in regression equations. For our purposes, it simply means we want to include a lagged endogenous variable, and that we should expect its effect on current measured inventories to be very strong.

The results are reported in Table 2. They show the hypothesized sign on all variables, usually with statistical significance. ${ }^{14}$ They thus generally support the model.

\section{Table 2: Relationship between oil inventories and real interest rates} Weekly data

(1114-1190 observations depending on data availability)

Non-stationary variables detrended by including quadratic terms in each regression

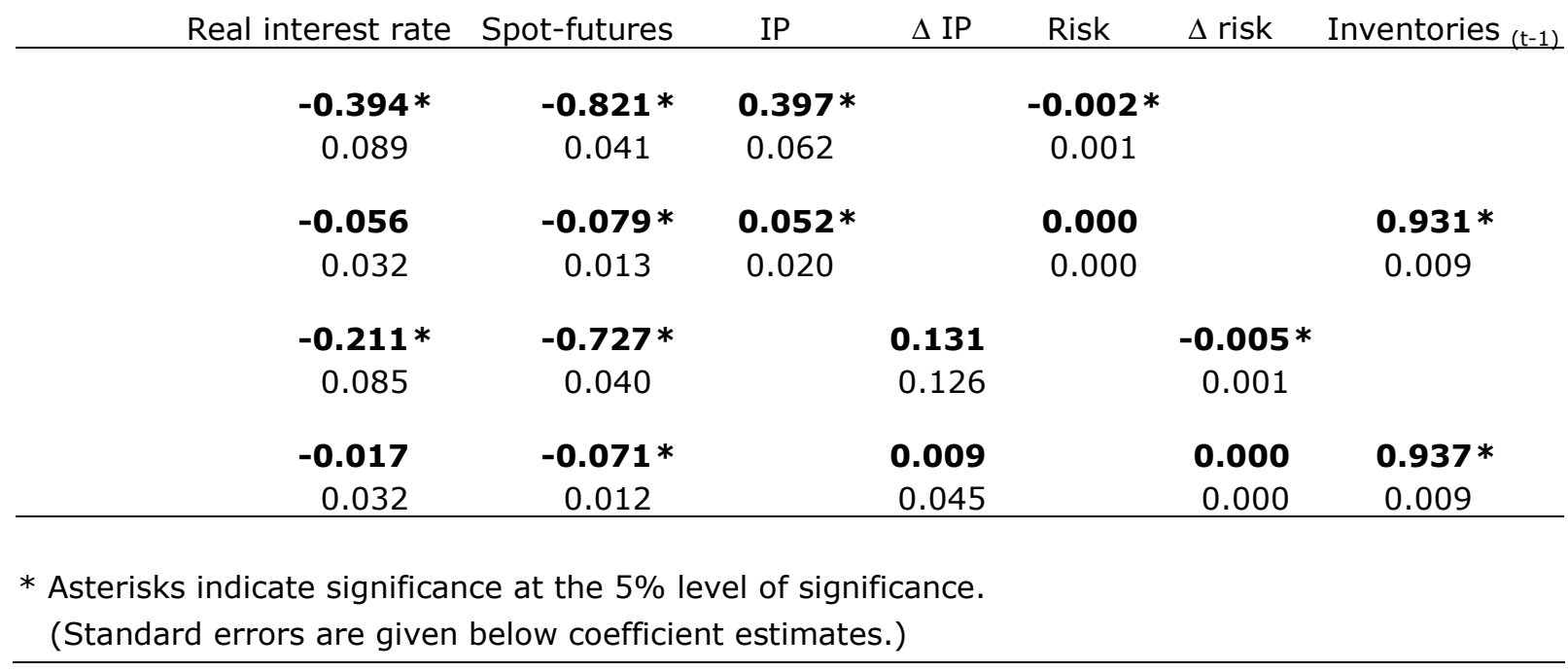

${ }^{14}$ Indeed, these other determinants are sufficiently successful in the inventory equation as to suggest that one include them in the regression estimates of equation (5), where they would serve as determinants of $c$. Perhaps the addition of such controls would improve the estimates of the macroeconomic influences on the prices of oil and other commodities. This extension is left for future research. 
We have also looked at agricultural inventories, as reported in Appendix 4 (Table 6). Here there is little evidence of an effect of real interest rates. But in this case we were unable to control for risk or other important variables, so perhaps this finding is to be expected.

\section{The relationship in other countries}

In the preceding analysis, we have expressed everything -- nominal commodity prices, CPI, interest rates -- in dollars. But the US is not the whole world. It is less than $1 / 3$ of Gross World Product, even if its importance in monetary and financial markets is evidently greater than that. In this section we consider other countries, concentrating on those that currently have floating exchange rates and thus are in need of a price target to anchor monetary policy. We will treat them as "small open economies," meaning that they take the world price of commodities as given, even though they range in size up to the United Kingdom.

\section{a. Adding exchange rate overshooting to commodity price overshooting}

We could begin by redoing the previous econometrics with global measures of each of the variables, i.e., measuring the commodity price in a GDP-weighted averages of the dollar, euro, yen, etc., measuring the world interest rate as a weighted average of national interest rates, and measuring the CPI and inflation rates as the same-weighted average of national CPIs and inflation rates. But we leave this as a possible extension for future research. Instead we take the US variables to be the global variables, and we proceed directly to look at small countries that by definition take the US/global variables as given.

The log spot price of the commodity in terms of currency $j$ is given by

$$
s_{j}=s_{(j / \$)}+s_{(\$ / c)},
$$

where $s_{(j / \$)}$ is the spot exchange rate in units of currency $j$ per $\$$ and $s_{(\$ / c)}$ is the spot price of commodity c in terms of $\$$, what has hitherto been called simply $s$ for the dollar case. The real exchange rate between currency $\mathrm{j}$ and the dollar is governed by the direct application of the Dornbusch overshooting model.

$\left(s_{(j / \$)}-\bar{S}_{(j / \$)}\right)-\left(p_{j}-\bar{p}_{j}\right)+\left(p_{\$}-\bar{p}_{\$}\right)=-(1 / v)\left(i_{j}-i_{\$}-\left[E\left(\Delta p_{j}\right)-E\left(\Delta p_{\S}\right)\right]\right)$.

Combining equations (5), (7), and (8), 


$$
\begin{aligned}
\left(s_{(j / c)}-\bar{s}_{(j / c)}\right) & =\left(s_{(j / \$)}-\bar{s}_{(j / \$)}\right)+\left(s_{(\$ / c)}-\bar{s}_{(\$ / c)}\right) \\
& =\left(p_{j}-\bar{p}_{j}\right)-(1 / v)\left(i_{j}-i_{\$}-\left[E\left(\Delta p_{j}\right)-E\left(\Delta p_{\$}\right)\right]\right)-(1 / \theta)\left(i_{\$}-E\left(\Delta p_{\$}\right)-\mathrm{c}\right) . \\
\left(q_{(j / c)}-\bar{q}_{(j / c)}\right) & =-(1 / v)\left(r_{j}-r_{\$}\right)-(1 / \theta)\left(r_{\$}-\mathrm{c}\right) .
\end{aligned}
$$

where

$r_{\$}$ is the US interest rate, and

$r_{j}$ is the interest rate in country $j$.

Equation (9) says the real commodity price observed in country $\mathrm{j}$ will be high to the extent either that the local real interest rate is low relative to the US real rate, or to the extent that the US real interest rate is low. We tested this equation for 8 individual countries that currently have independently floating currencies (though they did not all have floating rates throughout the entire sample period).

We computed the real commodity price by converting the commodity price to the currency of the small open economy in question, and dividing by the country's price level. We then regressed the log of the real commodity price on the two variables on the righthand side of equation (9), the US real interest rate and the differential in real interest rates between the small open economy and the US:

$$
\log \frac{C P^{U S} \bullet S^{\mathrm{j} / \$}}{P^{j}}=\alpha+\beta_{1}\left[\left(i^{j}-\pi^{j}\right)-\left(i^{U S}-\pi^{U S}\right)\right]+\beta_{2}\left(i^{U S}-\pi^{U S}\right)+\varepsilon
$$

The results for the 8 floating countries are reported in Tables $3 \mathrm{a}$ through $3 \mathrm{f}$. The tables use 6 different commodity price indices: CRB, Dow Jones, The Economist, Goldman Sachs, Moody's and Reuters. Monthly data were generally available for the developed countries from 1950. ${ }^{15}$ To take full advantage of what data were available, the regressions were estimated separately for the 3-month interest rate (3 month Treasury notes or equivalent) and the long term interest rate with the largest sample (Australia: 10 year bond; Brazil: 30 year bond; Canada: 10+ year bond; Chile: 20 year bond; Mexico: 3 year bond; NZ: 10 year bond; Switzerland: 30 year bond; UK: 20 year bond). The US interest rate for each regression was chosen to match the maturity of the bond from the small open economy.

\footnotetext{
${ }^{15}$ For the three Latin American countries, however, it was difficult to find interest rate data preceding their hyperinflations.
} 
Tables 3: Regressions of log real commodity prices in local currency on real interest rates Monthly observations (over largest possible sample of data since 1950)

* indicates coefficient significant at the 5\% level of significance. Robust standard errors are reported.

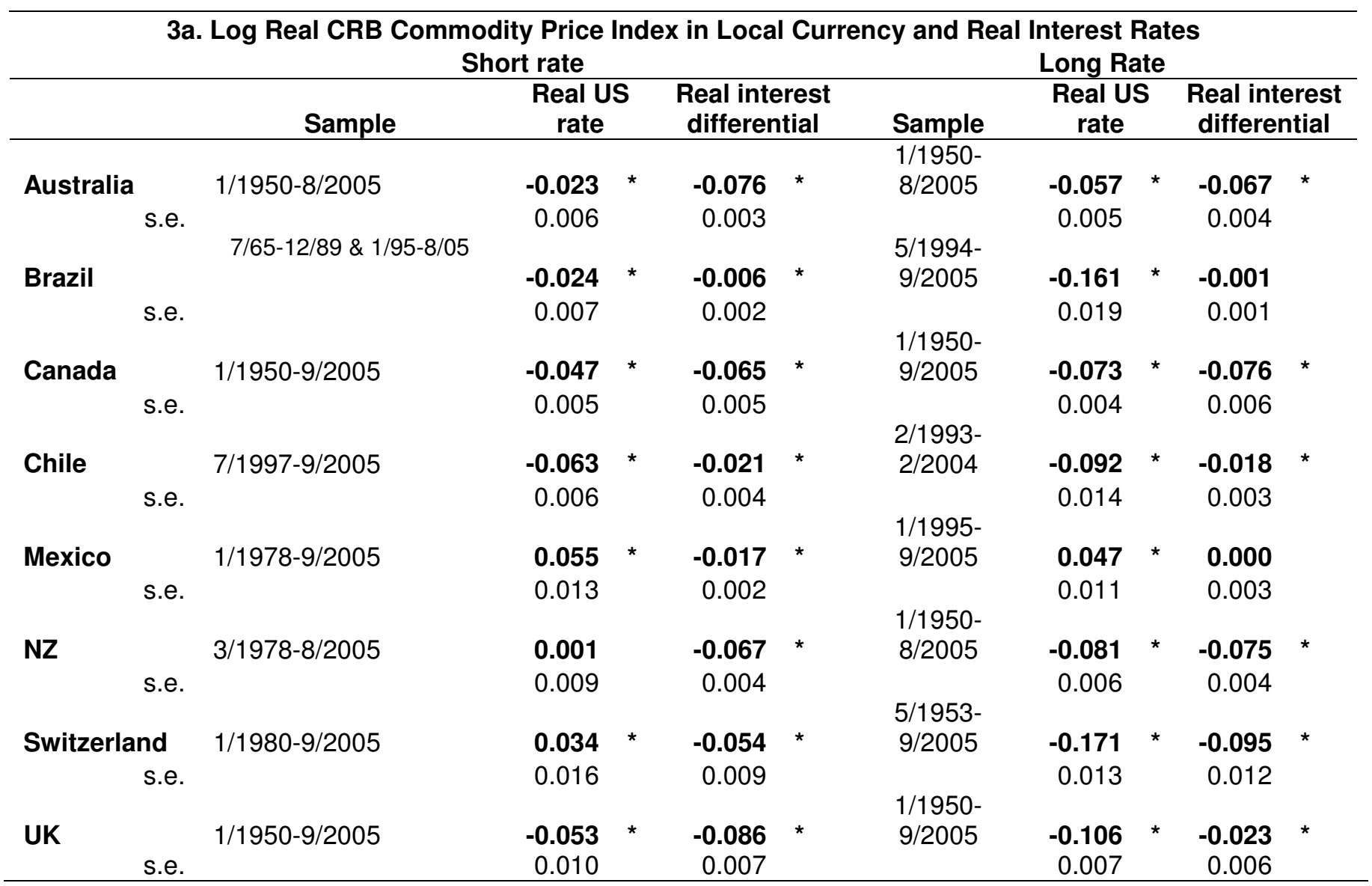

3b. Log Real Dow Jones Commodity Price Index in Local Currency and Real Interest Rates Short rate

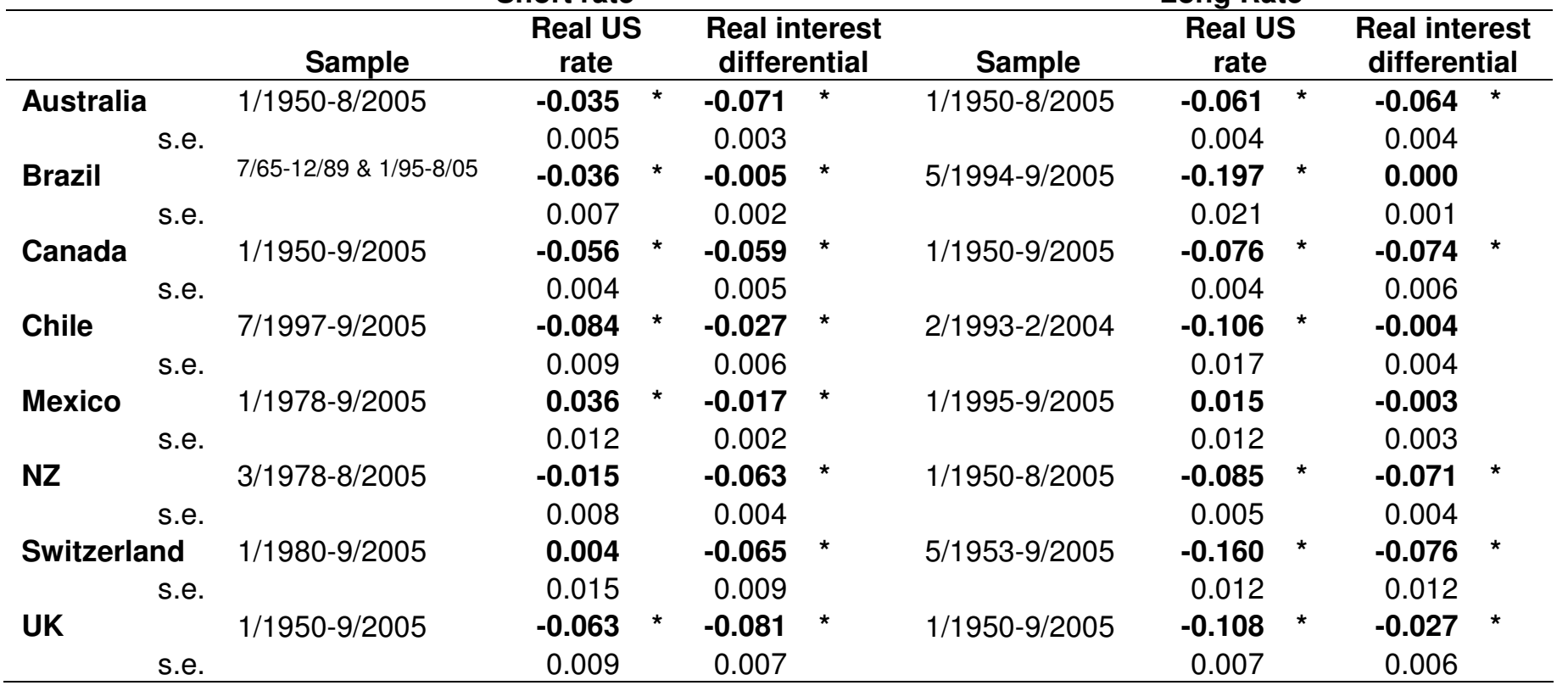




\begin{tabular}{|c|c|c|c|c|c|c|c|c|c|c|c|}
\hline \multicolumn{12}{|c|}{ 3c. Log Real Economist Commodity Price Index in Local Currency and Real Interest Rates } \\
\hline & & \multicolumn{5}{|c|}{ Short rate } & \multicolumn{5}{|c|}{ Long Rate } \\
\hline & & Sample & $\begin{array}{c}\text { Real US } \\
\text { rate }\end{array}$ & & $\begin{array}{l}\text { Real in } \\
\text { differ }\end{array}$ & $\begin{array}{l}\text { terest } \\
\text { ential }\end{array}$ & Sample & $\begin{array}{c}\text { Real U } \\
\text { rate }\end{array}$ & & $\begin{array}{l}\text { Real int } \\
\text { differer }\end{array}$ & $\begin{array}{l}\text { erest } \\
\text { itial }\end{array}$ \\
\hline Australia & & $1 / 1950-8 / 2005$ & -0.010 & * & -0.027 & * & $1 / 1950-8 / 2005$ & -0.018 & * & -0.031 & * \\
\hline & e. & & 0.005 & & 0.002 & & & 0.004 & & 0.002 & \\
\hline \multirow[t]{2}{*}{ Brazil } & $7 / 65$ & $5-12 / 89 \& 1 / 95-8 / 05$ & 0.005 & & -0.006 & * & 5/1994-9/2005 & -0.095 & * & -0.002 & * \\
\hline & e. & & 0.007 & & 0.001 & & & 0.018 & & 0.001 & \\
\hline \multirow[t]{2}{*}{ Canada } & & 1/1950-9/2005 & -0.012 & * & 0.004 & & 1/1950-9/2005 & -0.018 & * & -0.020 & * \\
\hline & e. & & 0.005 & & 0.005 & & & 0.004 & & 0.006 & \\
\hline \multirow[t]{2}{*}{ Chile } & & 7/1997-9/2005 & -0.049 & * & -0.011 & * & 2/1993-2/2004 & -0.020 & & -0.022 & * \\
\hline & e. & & 0.006 & & 0.004 & & & 0.014 & & 0.003 & \\
\hline \multirow[t]{2}{*}{ Mexico } & & 1/1978-9/2005 & 0.056 & * & -0.013 & * & 1/1995-9/2005 & 0.093 & * & 0.001 & \\
\hline & e. & & 0.012 & & 0.002 & & & 0.013 & & 0.004 & \\
\hline \multirow[t]{2}{*}{ NZ } & & 3/1978-8/2005 & 0.011 & & -0.042 & * & $1 / 1950-8 / 2005$ & -0.031 & * & -0.042 & * \\
\hline & e. & & 0.008 & & 0.003 & & & 0.005 & & 0.002 & \\
\hline \multicolumn{2}{|c|}{ Switzerland } & $1 / 1980-9 / 2005$ & 0.061 & * & -0.014 & & 5/1953-9/2005 & -0.086 & * & -0.051 & * \\
\hline & e. & & 0.013 & & 0.008 & & & 0.006 & & 0.006 & \\
\hline \multirow[t]{2}{*}{ UK } & & $1 / 1950-9 / 2005$ & -0.024 & * & -0.045 & * & $1 / 1950-9 / 2005$ & -0.049 & * & -0.021 & * \\
\hline & e. & & 0.007 & & 0.004 & & & 0.005 & & 0.004 & \\
\hline
\end{tabular}

3d. Log Real Goldman Sachs Commodity Price Index in Local Currency and Real Interest Rates Short rate

\begin{tabular}{|c|c|c|c|c|c|c|c|c|c|c|c|}
\hline \multirow[b]{2}{*}{ Australia } & & \multirow{2}{*}{$\begin{array}{c}\text { Sample } \\
12 / 1969-8 / 2005\end{array}$} & \multicolumn{2}{|c|}{$\begin{array}{c}\text { Real US } \\
\text { rate }\end{array}$} & \multicolumn{2}{|c|}{$\begin{array}{c}\text { Real interest } \\
\text { differential }\end{array}$} & \multirow{2}{*}{$\begin{array}{c}\text { Sample } \\
12 / 1969-8 / 2005\end{array}$} & \multicolumn{2}{|c|}{$\begin{array}{c}\text { Real US } \\
\text { rate }\end{array}$} & \multicolumn{2}{|c|}{$\begin{array}{c}\text { Real interest } \\
\text { differential }\end{array}$} \\
\hline & & & -0.054 & * & -0.063 & * & & -0.064 & * & -0.074 & * \\
\hline & s.e. & & 0.006 & & 0.004 & & & 0.005 & & 0.004 & \\
\hline \multirow[t]{2}{*}{ Brazil } & $12 / 6$ & $9-12 / 89 \& 1 / 95-8 / 05$ & -0.058 & * & -0.004 & * & 5/1994-9/2005 & -0.296 & * & -0.001 & \\
\hline & s.e. & & 0.009 & & 0.002 & & & 0.025 & & 0.001 & \\
\hline \multirow[t]{2}{*}{ Canada } & & 12/1969-9/2005 & -0.077 & * & -0.060 & * & 12/1969-9/2005 & -0.096 & * & -0.091 & * \\
\hline & s.e. & & 0.007 & & 0.007 & & & 0.006 & & 0.006 & \\
\hline \multirow[t]{2}{*}{ Chile } & & 7/1997-9/2005 & -0.098 & * & -0.048 & * & 2/1993-2/2004 & -0.178 & * & -0.007 & \\
\hline & s.e. & & 0.014 & & 0.009 & & & 0.021 & & 0.005 & \\
\hline \multirow[t]{2}{*}{ Mexico } & & $1 / 1978-9 / 2005$ & 0.026 & * & -0.015 & * & $1 / 1995-9 / 2005$ & -0.035 & * & -0.002 & \\
\hline & s.e. & & 0.011 & & 0.002 & & & 0.013 & & 0.004 & \\
\hline \multirow[t]{2}{*}{ NZ } & & 3/1978-8/2005 & -0.030 & * & -0.067 & * & 12/1969-8/2005 & -0.076 & * & -0.080 & * \\
\hline & s.e. & & 0.008 & & 0.003 & & & 0.007 & & 0.003 & \\
\hline \multicolumn{2}{|c|}{ Switzerland } & $1 / 1980-9 / 2005$ & -0.025 & & -0.077 & * & $12 / 1969-9 / 2005$ & -0.219 & * & -0.172 & * \\
\hline & s.e. & & 0.015 & & 0.009 & & & 0.009 & & 0.012 & \\
\hline \multirow[t]{2}{*}{ UK } & & $12 / 1969-9 / 2005$ & -0.051 & * & -0.089 & * & 12/1969-9/2005 & -0.094 & * & -0.039 & * \\
\hline & s.e. & & 0.009 & & 0.005 & & & 0.009 & & 0.007 & \\
\hline
\end{tabular}




\begin{tabular}{|c|c|c|c|c|c|c|c|c|c|c|c|}
\hline \multicolumn{12}{|c|}{ 3e. Log Real Moody's Commodity Price Index in Local Currency and Real Interest Rates } \\
\hline & & \multicolumn{5}{|c|}{ Short rate } & \multicolumn{5}{|c|}{ Long Rate } \\
\hline & & Sample & $\begin{array}{c}\text { Real US } \\
\text { rate }\end{array}$ & & $\begin{array}{l}\text { Real in } \\
\text { differ }\end{array}$ & $\begin{array}{l}\text { terest } \\
\text { ential }\end{array}$ & Sample & $\begin{array}{c}\text { Real U } \\
\text { rate }\end{array}$ & & $\begin{array}{r}\text { Real int } \\
\text { differe }\end{array}$ & $\begin{array}{l}\text { eres } \\
\text { tial }\end{array}$ \\
\hline \multirow{2}{*}{ Australia } & & $1 / 1950-8 / 2005$ & -0.031 & * & -0.052 & * & $1 / 1950-8 / 2005$ & -0.050 & * & -0.045 & * \\
\hline & s.e. & & 0.004 & & 0.002 & & & 0.003 & & 0.003 & \\
\hline \multirow[t]{2}{*}{ Brazil } & $7 / 6$ & $5-12 / 89 \& 1 / 95-8 / 05$ & -0.022 & * & -0.001 & & 5/1994-9/2005 & -0.180 & * & -0.001 & \\
\hline & s.e. & & 0.006 & & 0.001 & & & 0.023 & & 0.001 & \\
\hline \multirow[t]{2}{*}{ Canada } & & 1/1950-9/2005 & -0.044 & * & -0.040 & * & $1 / 1950-9 / 2005$ & -0.056 & * & -0.040 & * \\
\hline & s.e. & & 0.003 & & 0.004 & & & 0.003 & & 0.004 & \\
\hline \multirow[t]{2}{*}{ Chile } & & 7/1997-9/2005 & -0.096 & * & -0.021 & * & 2/1993-2/2004 & -0.055 & * & 0.004 & \\
\hline & s.e. & & 0.007 & & 0.005 & & & 0.020 & & 0.004 & \\
\hline \multirow[t]{2}{*}{ Mexico } & & 1/1978-9/2005 & 0.029 & * & -0.011 & * & 1/1995-9/2005 & 0.017 & & 0.000 & \\
\hline & s.e. & & 0.008 & & 0.002 & & & 0.012 & & 0.004 & \\
\hline \multirow[t]{2}{*}{ NZ } & & 3/1978-8/2005 & -0.021 & * & -0.044 & * & $1 / 1950-8 / 2005$ & -0.067 & * & -0.045 & * \\
\hline & s.e. & & 0.005 & & 0.002 & & & 0.004 & & 0.003 & \\
\hline \multicolumn{2}{|c|}{ Switzerland } & 1/1980-9/2005 & -0.030 & * & -0.071 & * & 5/1953-9/2005 & -0.117 & * & -0.046 & * \\
\hline \multirow{3}{*}{ UK } & s.e. & & 0.010 & & 0.006 & & & 0.009 & & 0.009 & \\
\hline & & $1 / 1950-9 / 2005$ & -0.054 & * & -0.059 & * & $1 / 1950-9 / 2005$ & -0.084 & * & -0.017 & * \\
\hline & s.e. & & 0.007 & & 0.005 & & & 0.005 & & 0.005 & \\
\hline
\end{tabular}

\begin{tabular}{|c|c|c|c|c|c|c|c|c|c|c|c|}
\hline \multicolumn{12}{|c|}{ 3f. Log Real Reuters Commodity Price Index in Local Currency and Real Interest Rates } \\
\hline & & \multicolumn{5}{|c|}{ Short rate } & \multicolumn{5}{|c|}{ Long Rate } \\
\hline & \multicolumn{2}{|r|}{ Sample } & \multicolumn{2}{|c|}{$\begin{array}{l}\text { Real US } \\
\text { rate }\end{array}$} & \multicolumn{2}{|c|}{$\begin{array}{c}\text { Real interest } \\
\text { differential }\end{array}$} & \multirow{2}{*}{$\begin{array}{c}\text { Sample } \\
11 / 1959-8 / 2005\end{array}$} & \multicolumn{2}{|c|}{$\begin{array}{l}\text { Real US } \\
\text { rate }\end{array}$} & \multicolumn{2}{|c|}{$\begin{array}{l}\text { Real interest } \\
\text { differential }\end{array}$} \\
\hline Australia & & $11 / 1959-8 / 2005$ & 0.009 & & -0.042 & * & & -0.008 & & -0.045 & * \\
\hline & e. & & 0.006 & & 0.004 & & & 0.005 & & 0.004 & \\
\hline \multirow[t]{2}{*}{ Brazil } & & 7/65-12/89 \& 1/95-8/05 & 0.003 & & -0.007 & * & $5 / 1994-9 / 2005$ & -0.060 & * & -0.003 & * \\
\hline & e. & & 0.008 & & 0.001 & & & 0.015 & & 0.000 & \\
\hline \multirow[t]{2}{*}{ Canada } & & 11/1959-9/2005 & -0.004 & & -0.004 & & 11/1959-9/2005 & -0.024 & * & -0.041 & * \\
\hline & e. & & 0.007 & & 0.006 & & & 0.006 & & 0.007 & \\
\hline \multirow[t]{2}{*}{ Chile } & & 7/1997-9/2005 & -0.029 & * & -0.007 & & 2/1993-2/2004 & -0.029 & * & -0.043 & * \\
\hline & e. & & 0.007 & & 0.004 & & & 0.013 & & 0.003 & \\
\hline \multirow[t]{2}{*}{ Mexico } & & $1 / 1978-9 / 2005$ & 0.088 & * & -0.014 & * & $1 / 1995-9 / 2005$ & 0.128 & * & 0.002 & \\
\hline & e. & & 0.014 & & 0.002 & & & 0.014 & & 0.005 & \\
\hline \multirow[t]{2}{*}{ NZ } & & 3/1978-8/2005 & 0.041 & * & -0.048 & * & 11/1959-8/2005 & -0.020 & * & -0.064 & * \\
\hline & e. & & 0.011 & & 0.004 & & & 0.006 & & 0.003 & \\
\hline \multicolumn{2}{|c|}{ Switzerland } & 1/1980-9/2005 & 0.102 & * & -0.011 & & 11/1959-9/2005 & -0.125 & * & -0.107 & * \\
\hline & e. & & 0.015 & & 0.009 & & & 0.008 & & 0.009 & \\
\hline \multirow[t]{2}{*}{ UK } & & 11/1959-9/2005 & 0.010 & & -0.070 & * & 11/1959-9/2005 & -0.037 & * & -0.018 & * \\
\hline & e. & & 0.009 & & 0.005 & & & 0.008 & & 0.006 & \\
\hline
\end{tabular}

In general, the evidence appears to support the hypothesis regarding the determination the log real local-currency index of commodity prices. The estimates show a significant negative coefficient on the real US interest rate, representing global monetary policy, as well as on the real interest differential between the national economy and the US, representing local variations in monetary stance. Often significance levels are high. In the case of the three major English-speaking countries, Australia, Canada and the United Kingdom, both the coefficient on the US real interest rate and the coefficient on the real 
interest differential are statistically significant and of the hypothesized negative sign in almost every one of the 12 cases, regardless which of the 6 commodity price indices are used and regardless whether short-term or long-term interest rates are used. The results for New Zealand and Switzerland are almost as strong but for the effect of the short-term US rate; as are the results for Brazil and Chile, except that the coefficient on the longterm real interest differential is not always significant. The only disappointing country is Mexico, where even though the short-term real interest differential always appears significantly less than zero, the US interest rate appears significantly greater than zero rather than less.

This seems impressive evidence for what has been the central theme of this paper so far. The hypothesized effect of the real interest rate on real commodity prices works not only at the US level, but also at the level of local variation among open economies above and beyond the global phenomenon.

\section{Implications for Monetary Policy}

We conclude the paper with a consideration of some implications for monetary policy makers. The first implication is a reason to add commodity prices to the list of variables that central banks monitor, regardless what is their regime-i.e., regardless whether they use discretion or some rule or intermediate target, and in the latter case regardless what is the rule or target that is officially declared. The second implication concerns the possibility, in the case of countries where fluctuations in the terms of trade are important, of giving export prices a larger role in the price index that enters the rule or target than does the CPI (whether headline CPI or core CPI).

\section{Commodity Prices Belong on the List of Monetary Conditions Indicators}

The advice that monetary policy makers should "look at everything" sounds easy to give and hard to reject. But not everyone would consider it obvious that an index of agricultural and mineral commodity prices belongs on a useful list of variables to reveal current monetary conditions, alongside short and long-term interest rates, the exchange rate, housing prices, and the stock market. The conventional practice is to throw the volatile "food and energy" sector out of the price indices, concentrating instead on the core CPI if one wants a good indicator of likely future inflation. It is certainly true that if one is looking for the single standard statistic that best predicts future inflation, the core CPI will do better than the headline CPI. But that is not the question. The question is, rather, if one is free to look at lots of information, are agricultural and mineral prices on the list of variables worth paying attention to? This perspective places this chapter on a plane with other chapters that consider the possibility of central banks paying attention to housing prices or the stock market.

The theory and empirical results reported in this paper suggest that the answer is "yes." Real commodity prices reflect monetary ease, more specifically real interest rates, among other factors. We can never be sure what the real interest rate is, because 
we do not directly observe expected inflation. Thus it is useful to have additional data that are thought to reflect real interest rates.

\section{What Prices Belong in the Inflation Targeters' Target?}

The current fashion in monetary policy regimes is inflation targeting. Such countries as the United Kingdom, Sweden, Canada, New Zealand, Australia, Chile, Brazil, Norway, Korea, and South Africa have adopted it, and many monetary economists approve. In part this is a consequence of the disillusionment with exchange rate targets that arose in the course of ten years of the currency crises of the last ten years (from the speculative attack that forced the UKMexico 1994 to drop out of the European Exchange Rate Mechanism in 1992 to the Argentina crisis of 2001). Proponents of inflation targeting point out that if the exchange rate is not to be the anchor for monetary policy, then the ultimate objective of price stability requires that some new nominal variable must be chosen as the anchor. Two old favorite candidates for nominal anchor, the price of gold and the money supply, have long since been discredited in the eyes of many. So that seems to leave inflation targeting. One version of a generalized approach to inflation targeting is a Taylor rule, which puts weight on output in addition to inflation.

But whether it is simple inflation targeting or a Taylor rule, what price index is appropriate? Of the possible price indices that a central bank could target, the CPI is the usual choice. Indeed the CPI (whether core or overall CPI) seems to be virtually the only choice that central banks and economists have even considered. But this is not the only possible choice. A proposal made elsewhere is to target an index of export prices.

\section{The Proposal to Peg the Export Price (PEP)}

This idea is a more moderate version of an exotic-sounding proposed monetary regime called Peg the Export Price - or PEP, for short. The author originally proposed PEP explicitly for those countries that happen to be heavily specialized in the production of a particular mineral or agricultural export commodity. The proposal was to fix the price of that commodity in terms of domestic currency, or, equivalently, set the value of domestic currency in terms of that commodity. For example, African gold producers would peg their currency to gold - in effect returning to the long-abandoned gold standard. Middle Eastern oil producersCanada and Australia would peg to oil. Coffee producerswheat. Norway would peg to coffee, wheat producersoil. Chile would peg to wheatcopper, and so forth. One can even think of exporters of manufactured goods that qualify: standardized semi-conductors (that is, commodity chips) are sufficiently important exports in Korea and some other East Asian countries that one could imagine these countriesit pegging the won to the price of chips.

How would this work operationally? Conceptually, one can imagine the government holding reserves of gold or oil, and intervening whenever necessary to keep the price fixed in terms of local currency. Operationally, a more practical method would be for the central bank each day to announce an exchange rate vis-à-vis the dollar, following the rule that the day's exchange rate target (dollars per local currency unit) moves precisely in proportion to the day's price of gold or oil on the London market or 
New York market (dollars per commodity). Then the central bank could intervene via the foreign exchange market to achieve the day's target. Either way, the effect would be to stabilize the price of the commodity in terms of local currency. Or perhaps, since these commodity prices are determined on world markets, a better way to express the same policy is "stabilizing the price of local currency in terms of the commodity."16

The PEP proposal can be made more moderate, and more appropriate for diversified economies, in a number of ways, as explained in the next subsection. ${ }^{17}$ One way is to interpret it as targeting a broad index of all export prices, rather than the price of only one or a few export commodities. This moderate form of the proposal is abbreviated PEPI, for Peg the Export Price Index. ${ }^{18}$

The argument for the export price targeting proposal, in any of its forms, is stated succinctly: It delivers one of the main advantages that a simple exchange rate peg promises, namely a nominal anchor, while simultaneously delivering one of the main advantages that a floating regime promises, namely automatic adjustment in the face of fluctuations in the prices of the countries' exports on world markets. Textbook theory says that when there is an adverse movement in the terms of trade, it is desirable to accommodate it via a depreciation of the currency. When the dollar price of exports rises, under PEP or PEPI the currency per force appreciates in terms of dollars. When the dollar price of exports falls, the currency depreciates in terms of dollars. Such accommodation of terms of trade shocks is precisely what is wanted. In recent currency crises, countries that suffered a sharp deterioration in their export markets were often eventually forced to give up their exchange rate targets and devalue anyway; but the adjustment was far more painful -- in terms of lost reserves, lost credibility, and lost output -- than if the depreciation had happened automatically.

But the proposal is not just for countries with volatile commodity exports. The desirability of accommodating terms of trade shocks is a good way to summarize the attractiveness of export price targeting relative to the reigning champion, CPI targeting. ${ }^{19}$ Consider the two categories of adverse terms of trade shocks: a fall in the dollar price of the export in world markets and a rise in the dollar price of the import on world markets. In the first case, a fall in the export price, you want the local currency to depreciate against the dollar. As already noted, PEP or PEPI deliver that result automatically; CPI targeting does not. In the second case, a rise in the import price, the terms-of-trade criterion suggests that you again want the local currency to depreciate. ${ }^{20}$ CPI targeting actually has the implication that you tighten monetary policy so as to appreciate the currency against the dollar, by enough to prevent the local-currency price of imports from

\footnotetext{
${ }^{16}$ Frankel $(2002,2003)$ and Frankel and Saiki (2002).

17 Another way to go is to define as the parity a basket that includes the export commodity as well as a weighted average of currencies of major trading partners - e.g., 1/3 dollars, 1/3 euros, and 1/3 oil, as the author has proposed for Persian Gulf states.

18 Frankel (2005).

${ }^{19}$ Among many possible references are Bernanke, et al. (1999), Mankiw and Reis (2003), Svensson (1995, 1999), Svennson and Woodward (2005), and Truman (2003).

${ }^{20}$ Neither regime delivers that result. There is a reason for this. In addition to the goal of accommodating terms of trade shocks, there is also the goal of resisting inflation; but to depreciate in the face of an increase in import prices would exacerbate price instability.
} 
rising. This implication - reacting to an adverse terms of trade shock by appreciating the currency - seems perverse. It could be expected to exacerbate swings in the trade balance, and output.

Few believe that the proper response for an oil-importing country in the event of a large increase in world oil prices is to tighten monetary policy and thereby appreciate the currency sufficiently to prevent an increase in the price of oil in terms of domestic currency. The usual defense of inflation targeting offered by its many proponents is that in the event of such a shock, the central bank can easily deviate from the CPI target and explain the circumstances to the public. But what can be the argument for making such derogations on an ad hoc basis, when it is possible to build them into a simple target rule in the first place? Certainly not a gain in transparency and credibility.

This is not to suggest that this regime would be appropriate for all countries, only that it might have advantages for countries that experience large volatility in their terms of trade. But it has become apparent in this decade that terms of trade volatility is a more serious issue than was believed in the 1980s and 1990s.

To summarize, the argument for PEPI over CPI targeting is two-fold. First, CPI targeting requires tightening in the face of an increase in the world price of import commodities, such as oil for an oil importer, while PEPI does not. Second, PEPI allows accommodation of fluctuations in the world price of the export commodities, while CPI targeting does not.

\section{Moderate Version: Peg the Export Price Index}

The second of the two arguments for the PEPI proposal just given is to eliminate export price variability. The stability in export prices, in turn, would help stabilize the balance of payments. It would, for example, have allowed the Korean won to depreciate automatically in the late 1990s, without the need for a costly failed attempt to defend an exchange rate target before the devaluation. ${ }^{21}$ It would have allowed the Malaysian ringgit to appreciate automatically in the early 2000s, without the need for the monetary authorities to abandon their nominal anchor, as they did formally in 2005.

How would PEPI be implemented operationally? That is, how would an index of export prices be stabilized? As noted, in the simple version of the PEP proposal, there is nothing to prevent a central bank from intervening to fix the price of a single agricultural or mineral product perfectly on a day-to-day basis. Such perfect price fixing is not possible in the case of a broad basket of exports, as called for by PEPI, even if it were desirable. For one thing, such price indices are not even computed on a daily basis. So it would be, rather, a matter of setting a target zone for the year, with monthly realizations, much as a range for the CPI is declared under the most standard interpretation of inflation targeting.

\footnotetext{
${ }^{21}$ Earlier research reported simulations of the path of exports over the last three decades if countries had followed the PEP proposal, as compared to hypothetical rigid pegs to a major currency, or as compared to whatever policy the country in fact followed historically: Frankel (2002) focuses primarily on producers of gold, Frankel (2003) on oil exporters, and Frankel and Saiki (2002) on various other agricultural and mineral producers. A typical finding was that developing countries that suffered a deterioration in export markets in the late 1990s, often contributing to a financial crisis, would have adjusted automatically under the PEP regime.
} 
The declared band could be wide if desired, just as with the targeting of the CPI, money supply, exchange rate, or other nominal variables. Open market operations to keep the export price index inside the band if it threatens to stray outside could be conducted in terms either of foreign exchange or in terms of domestic securities. For some countries, it might help to monitor on a daily or weekly basis the price of a basket of agricultural and mineral commodities that is as highly correlated as possible with the country's overall price index, but whose components are observable on a daily or weekly basis in well-organized markets. The central bank could even announce what the value of the basket index would be one week at a time, by analogy with the Fed funds target in the United States. The weekly targets could be set so as to achieve the medium-term goal of keeping the comprehensive price index inside the pre-announced bands; and yet the central bank could hit the weekly targets very closely, if it wanted, for example, by intervening in the foreign exchange market.

A first step for any central bank wishing to dip its toe in these waters would be to compute a monthly index of export prices and publish it. A second step would be to announce that it was "monitoring" the index. The data requirements for computing such an index would not be great. Every country's customs services gathers data on trade volumes and prices; indeed they tend to do so at earlier stages of development than they gather data on national income or the CPI. For countries that lack fully credible institutions, an added advantage of the PEP proposal is transparency: the components tend to be more readily observable than components of the CPI such as prices of housing or other nontraded services.

A still more moderate, still less exotic-sounding, version of the PEPI proposal would be to target a producer price index (PPI) or the GDP deflator. In practice, it can be difficult to separate production cleanly into the two sectors, nontraded goods and exportables, in which case the two versions of the proposal - targeting an export price index or a producer price index -- come down to the same thing. The key point of the PEP proposal is to exclude import prices from the index, and to include export prices (as the PPI also does). The problem with CPI targeting is that it does it the other way around. 


\section{$* * * * * * * * * * * * * * * * * * \mathrm{DROP} * * * * * * * * * * * * * * * * * * * * * *$}

Among the many travails of developing countries in recent years have been fluctuations in world prices of the commodities that they produce, especially mineral and agricultural commodities, as well as fluctuations in the foreign exchange values of major currencies, especially the dollar, yen, and euro. Some countries see the currency to which they are linked moving one direction, while their principal export commodities move the opposite direction.

Consider the difficult position of Argentina, the victim of the worst emerging market financial crisis of 2001. As is well-known, Argentina's "convertibility plan," a rigid currency board, was very successful at eliminating very high inflation rates when it was first instituted in 1991, but later turned out to be unsustainably restrictive. Perhap it would have been impossible in any case to obey constraints as demanding as the straightjacket of the currency board. But Argentina's problems in the late 1990s became especially severe because the link was to a particular currency, the US dollar, that appreciated sharply against other major currencies, beginning in mid-1995. At the same time, the market for Argentina's important agricultural export products (wheat, meat, and soybeans), declined sharply. Thus the declines in the prices of these commodities expressed in terms of dollars were particularly dramatic. The combination led directly to sharp increases in the ratio of debt to exports. Although the particular strong dollar episode was not predictable when the currency regime was adopted in 1991, the likelihood that large swings of this sort would eventually occur was predictable. This is because the correlation is low between the value of the dollar and the value of commodities (expressed in some common numeraire). It was only a matter of time until they went sharply in opposite directions.

Argentina's difficulties encouraged some to reconsider whether a currency board is a good idea after all. ${ }^{22}$ But perhaps more thought should be given to what anchor the peso has been pegged to, rather than the tightness of the peg.

The author has suggested a new proposal, called PEP, for Peg the Export Price. The idea is more obviously relevant for a country that is relatively specialized in the production and export of a particular mineral or agricultural commodity. But it also applies to floaters where the terms of trade shocks show up on the import side, particularly with respect to oil. The proposal is to commit to a monetary policy that fixes the local-currency price of the export commodity. It is not a proposal to try to stabilize the dollar price of the commodity; that would be futile, especially under the assumption that the country in question is too small to affect the commodity price on world markets. Operationally, the most practical way to implement the PEP proposal might be for the local central bank to announce a daily exchange rate against the dollar that varies perfectly with the dollar price of the commodity in question on world markets, and to intervene to defend that exchange rate. That technique would be equivalent to fixing the price of the commodity in terms of local currency.

Monetary theorists have in the past emphasized a particular argument in favor of regimes that fix the value of money: as a means for the central bank to establish a credible commitment against inflation. This argument usually leaves out the question whether one means of fixing the value of the money is superior to another. It is as if it doesn't matter whether the anchor is the dollar or the Swiss franc or gold, or any other stable currency or commodity. In reality, the choice of anchor can make an important difference. Lithuania can get into trouble if it links it currency to the dollar, when most of its trade is with Europe; the euro would be better, because so much of Lithuania's trade is with the European Union. Analogously, Argentina might be better off pegging to wheat, than pegging to the dollar. Ghana might be better off pegging to gold. Chile might be better off pegging to copper. Venezuela might be better off pegging to oil.

\section{Pros and cons of different monetary regimes}

Much has been written on the arguments for fixed versus flexible exchange rates. ${ }^{23}$

\section{a. The Nominal Anchor Argument for Fixing the Value of Currency}

There are a variety of advantages to fixed exchange rates. In recent decades, the leading argument for firmly fixing exchange rates is as a credible commitment by the central bank, to affect favorably the expectations of those who determine wages, prices, and international capital flows by convincing them that they need not fear inflation or depreciation. The desire for a credible commitment to a stable monetary policy arose as a reaction to the high inflation rates of the 1970s, which in the 1980s reached hyperinflation levels in a number of developing countries. But fixing the value of the domestic currency in terms of foreign currency is not the only way that a country can seek a credible institutional commitment to non-inflationary monetary policy.

Governments can achieve anti-inflation credibility by being seen to tie their hands in some way so that in the future they cannot follow expansionary policies even if they want to. Otherwise, they may be tempted in a particular period (such as an election year) to reap the short-run gains from expansion, knowing that the major policies even if they want to. Otherwise, they may be tempted in a particular period (such as an election year) to reap the short-run gains from expansion, knowing that the major
inflationary costs will not be borne until the future. A central bank can make a binding commitment to refrain from excessive money creation via a rule, a public commitment to inflationary costs will not
fix a nominal magnitude.

Monetary unions, currency boards or other firm exchange rate pegs constitute one of a number of possible nominally anchored monetary regimes. Others include monetarism, inflation targeting, nominal income targeting, and a gold standard. In each case, the central bank is deliberately constrained by a rule setting monetary policy so as to fix a particular magnitude - the exchange rate, the money supply, the inflation rate, nominal income, or the price of gold. Monetary policy is automatically tightened if the magnitude in question is in danger of rising above the pre-set target, and is automatically loosened if the magnitude is in danger of falling below the target. The goal of such nominal anchors is to guarantee price stability.

Preventing excessive money growth and inflation is the principal "pro" argument for fixing the price of gold or some other nominal anchor. What are the disadvantages? The overall argument against the rigid anchor is that a strict rule prevents monetary policy from changing in response to the needs of the economy. The general problem of mismatch between the constraints of the anchor and the needs of the economy can take three forms: (1) loss of monetary independence, (2) loss of automatic general problem of mismatch between the constraints of the
adjustment to export shocks, and (3) extraneous volatility.

First, under a free-floating currency, a country has monetary independence. In a recession, when unemployment is temporarily high and real growth temporarily low, the central bank can respond by increasing money growth, lowering interest rates, depreciating the currency, and raising asset prices, all of which work to mitigate the downturn. Under a pegged currency, however, the central bank loses that sort of freedom. It must let recessions run their course. But the last few decades have seen widespread disillusionment, both among academics and practitioners, with the proposition that governments are in practice able to use discretionary monetary policy in an intelligent and useful way. This is particularly true in the case of developing countries. As a consequence, the trend in the 1990 s was away from government discretion in monetary policy and toward the constraints of nominal anchors.

The second point is that even if the central bank lacks the reflexes to pursue a skillful and timely discretionary monetary policy, under a floating exchange rate a deterioration in the international market for a country's exports should lead to an automatic fall in the value of its currency. The resulting stimulus to production will mitigate the downturn even without any deliberate action by the government. Some have argued, for example, that Australia came through the 1997-98 Asian crisis in relatively good shape because its currency was free to depreciate automatically in response to the deterioration of its export markets. Canada, New Zealand and Norway, like Australia, are said to be commodity-exporting countries with floating currencies that automatically depreciate when the world market for their export commodities is weak. Again, this mechanism is normally lost under a rigid nominal anchor

A third consideration makes the pegging problem still more difficult. If a country has rigidly linked its monetary policy to some nominal anchor, exogenous fluctuations in that anchor will create gratuitous fluctuations in the country's monetary conditions that may not be positively correlated with the needs of that particular economy.

\section{b. Each Candidate for Nominal Anchor has its Own Vulnerability} monetary system

Each of the various magnitudes that are candidates for nominal anchor has its own characteristic sort of extraneous fluctuations that can wreck havoc on a country's

A monetarist rule would specify a fixed rate of growth in the money supply. But fluctuations in the public's demand for money or in the behavior of the banking system can directly produce gratuitous fluctuations in velocity and the interest rate, and thereby in the real economy. For example, in the United States, a large upward shift in the demand for money around 1982 convinced the Federal Reserve Board that it had better abandon the money growth rule it had adopted two years earlier, or else face a prolonged and severe recession.

To some, the novel idea of pegging the currency to the price of the export good, which this study puts forward, may sound similar to the current fashion of targeting the inflation rate or price level. ${ }^{24}$ But the fashion, in such countries as the United Kingdom, Sweden, Canada, New Zealand, Australia, Chile, Brazil and

\section{${ }^{22}$ Edwards (2002). \\ ${ }^{23}$ Recent surveys appear in Edwards (2002), Eichengreen (1994), and Frankel (1999, 2003).}


South Africa, is to target the CPI. A key difference between the CPI (or GDP deflator) and the export price is the terms of trade. When there is an adverse movement in the terms of trade, one would like the currency to depreciate, while price level targeting can have the opposite implication. If the central bank has been constrained to hit an inflation target, positive oil price shocks (as in 1973, 1979, or 2000), for example, will require an oil-importing country to tighten monetary policy. The result can be sharp falls in national output. Thus under rigid inflation targeting, supply or terms-of-trade shocks can produce unnecessary and excessive fluctuations in the level of economic activity.

- The need for robustness with respect to import price shocks argues for the superiority of nominal income targeting over inflation targeting. ${ }^{25}$ A practical argument against nominal income targeting is the difficulty of timely measurement, and the problem of subsequent revisions.

- Under a gold standard, the economy is hostage to the vagaries of the world gold market. For example, when much of the world was on the gold standard in the 19th century, global monetary conditions depended on the output of the world's gold mines. The California gold rush from 1849 was associated with a midcentury increase in liquidity and a resulting increase in the global price level. The absence of major discoveries of gold between 1873 and 1896 helps explain why price levels fell dramatically over this period. In the late 1890s, the gold rushes in Alaska and South Africa were each again followed by new upswings in the price level. Thus the system did not in fact guarantee stability. ${ }^{26}$

- $\quad$ One proposal is that monetary policy should target a basket of basic mineral and agricultural commodities. The idea is that a broad-based commodity standard of this sort would not be subject to the vicissitudes of a single commodity such as gold, because fluctuations of its components would average out somewhat. ${ }^{27}$ The proposal might work if the basket reflected the commodities produced and exported by the country in question. But for a country that is a net importer of oil, wheat, and othe mineral and agricultural commodities, such a peg gives precisely the wrong answer in a year when the prices of these import commodities go up. Just when the domestic currency should be depreciating to accommodate an adverse movement in the terms of trade, it appreciates instead. Brazil should not peg to oil, and Kuwait should not peg to wheat.

- Under a fixed exchange rate, fluctuations in the value of the particular currency to which the home country is pegged can produce needless volatility in the country's international price competitiveness. For example, the appreciation of the dollar from 1995 and 2001 was also an appreciation for whatever currencies were linked to the dollar. Regardless the extent to which one considers the late-1990s dollar appreciation to have been based in the fundamentals of the US economy, there was no necessary connection to the fundamentals of smaller dollar-linked economies. The problem was particularly severe for some far-flung economies that had adopted currency boards over the connection to the fundamentals of smaller dollar-linked econ
preceding decade: Hong Kong, Argentina, and Lithuania.

To recap, each of the most popular variables that have been proposed as candidates for nominal anchors is subject to fluctuations that will add an element of unnecessary monetary volatility to a country that has pegged its money to that variable: velocity shocks in the case of M1, supply shocks in the case of inflation targeting, measurement errors in the case of nominal GDP targeting, fluctuations in world gold markets in the case of the gold standard, and fluctuations in the anchor currency in the case of exchange rate pegs.

Consider further the case of pegs to the dollar or other major currencies. Each of the currency crisis victims listed above (1994-2001) has since abandoned its links to the dollar or to the basket that included the dollar -- as have Chile, Colombia and others - in favor of greater flexibility. Nevertheless, they continue to exhibit a "fear of floating." Brazil found in 2002 that free floating offered little protection against financial pressure. Few countries are comfortable that they have found the right answer. Alternative suggestions are still welcome.

\section{c. Conclusion: The Case for PEP}

That leaves us with the question: given a degree of commitment by a country to fix the value of its currency, what anchor should it use? This question is best illustrated - not by those countries who have abandoned pegs for enhanced flexibility, nor even by those who have moved in the opposite direction -- but, rather, by a country that has moved from one rigid peg to another. Lithuania, while retaining a currency board arrangement, responded to the difficulties created by the late-1990s appreciation of the dollar by switching recently from a dollar anchor to the euro. Argentina also debated some sort of switch. Economy Minister Cavallo, in 2001 before his resignation and the abandonment of the convertibility system, had announced an eventual move to a currency board with an anchor defined as a basket of one half dollar and one half euro. In both cases, a large part of the motivation was an overvaluation stemming from the late-90s appreciation of the dollar.

The strong dollar of 1996-2001 was a transitory phenomenon. During the preceding period, from 1988 to 1995, the dollar was weak. When the dollar weakens again, it will be the countries that are pegged to the euro that will lose competitiveness. The relevant question is the choice of regime for the longer term, when it is not known which currencies will be weak and which strong, but it is expected that swings in both directions will eventually occur.

For those countries that want a nominal anchor and that happen to have exports concentrated in a mineral or agricultural commodity, a peg to that commodity may in fact make perfect sense. For them fluctuations in the international value of their currency that follow from fluctuations in world commodity market conditions would not be an extraneous source of volatility. Rather they would be precisely the sort of movements that are desired, to accommodate exogenous changes in the terms of trade and minimize their overall effect on the economy. In these particular circumstances, the automatic accommodation or insulation that is normally thought to be the promise held out only by floating exchange rates, is instead delivered per force by the pegging option. Thus PEP gives the best of both worlds: adjustment to trade shocks and the nominal anchor. The PEP proposal is not just for small developing countries, or the few rich countries that export commodities (Australia, Canada, and Norway). It also dominates CPI targeting for those countries where terms of trade uncertainty comes on the import side rather than the export side - in particular, for oil importers like Japan, Korea, New Zealand, Singapore, Sweden and Switzerland. Currently these floaters are told to target the CPI. But this rule, if interpreted literally, would tell the monetary authorities in these countries that when they are faced with an oil shock, they must tighten monetary policy sufficiently so that the price of oil, and thereby the CPI, does not rise in terms of their home currencies. Such a monetary contraction would require a currency appreciation against the dollar equal to the rise in the dollar price of oil, which is likely to be far too restrictive. Targeting a basket without oil, like the producer price index or an export price index does not have this problem.

\section{${ }^{24}$ Among many possible references are Svensson (1995) and Bernanke, et al. (1999).}

${ }^{25}$ Velocity shocks argue for the superiority of nominal income targeting over a monetarist rule. Frankel (1995) demonstrates the point mathematically, using the framework of Rogoff (1985), and gives other references on nominal income targeting.

${ }^{26}$ Cooper (1985) or Hall (1982).

${ }^{27}$ A "commodity standard" was proposed in the 1930s - by B. Graham (1937) - and subsequently discussed by Keynes (1938), and others. It was revived in the 1980s: e.g., Hall (1982). 


\section{$\underline{\text { References }}$}

Abosedra, Salah; Radchenko, Stanislav (2003), "Oil Stock Management and Futures Prices: An Empirical Analysis," Journal of Energy and Development, vol. 28, no. 2, Spring 2003, pp. 173-88

Balabanoff, Stefan (1995), "Oil Futures Prices and Stock Management: A Cointegration Analysis", Energy Economics, vol. 17, no. 3, July 1995, pp.205-10.

Barsky, Robert, and Lawrence Summers (1988) "Gibson's Paradox and the Gold Standard," Journal of Political Economy, 96, no. 3, pp. 528-550.

Bernanke, Ben, Thomas Laubach, Frederic Mishkin, and Adam Posen (1999), Inflation Targeting: Lessons from the International Experience, Princeton University Press: Princeton NJ.

Bessimbinder, Hendrik (1993). "An Empirical Analysis of Risk Premia in Futures Markets". Journal of Futures Markets, 13, pp. 611-630.

Bordo, Michael, and Anna J. Schwartz (1996), "The Specie Standard as a Contingent Rule: Some Evidence for Core and Peripheral Countries, 1880-1990" in Currency Convertibility: The Gold Standard and Beyond, J. Braga de Macedo, B. Eichengreen, J. Reis, eds., pp. 11-83 (New York: Routledge).

Breeden, Douglas (1980), "Consumption Risks in Futures Markets," Journal of Finance, vol. 35, 503-20, May.

Brenner, Robin and Kroner, Kenneth (1995), “Arbitrage, Cointegration, and Testing Unbiasedness Hypothesis in Financial Markets," Journal of finance and Quantitative Analysis 30, 23-42.

Choe, Boum-Jong(1990), "Rational expectations and commodity price forecasts," Policy Research Working Paper Series," 435, The World Bank.

Cooper, Richard (1985), "The Gold Standard: Historical Facts and Future Prospects" Brookings Papers on Economic Activity, 1, 1-45.

Covey, Ted \& Bessler, David A. (1995), "Asset Storability and the Information Content of Intertemporal Prices,” Journal of Empirical Finance, 2, pp. 103-15.

Deffeyes, Kenneth (2005), Beyond Oil: The View from Hubbert's Peak (Hill and Wang).

Dornbusch, Rudiger (1976), "Expectations and Exchange Rate Dynamics," Journal of Political Economy 84, 1161-1176.

Dusak, Katherine (1973), "Futures Trading and Investor Returns: An Investigation of Commodity Market Risk Premiums," Journal of Political Economy, 81, 1387-1406.

Edwards, Sebastian (2002), "The Great Exchange Rate Debate After Argentina," NBER Working Paper No. 9257, October.

Edwards, Sebastian and Eduardo Levy Yeyati (2003), "Flexible Exchange Rates as Shock Absorbers," NBER Working Paper No. 9867, July. 
Eichengreen, Barry (1985), The Gold Standard in Theory and History. New York, Methuen.

Fama, Eugene, \& French, Kenneth R. (1987), "Commodity Futures Prices: Some Evidence on Forecast Power, Premiums, and the Theory of Storage," Journal of Business, 60, 55-73.

Fortenbery, Randall, and Zapata, Hector (1997), "An Evaluation of Price Linkages Between Futures and Cash Markets for Cheddar Cheese." The Journal of Futures Markets, vol.17, May 1997, page 279-301.

Frankel, Jeffrey (1986), "Expectations and Commodity Price Dynamics: The Overshooting Model," Amer. J. of Agric. Ec. 68, no. 2, pp. 344-348. Reprinted in Frankel, Financial Markets and Monetary Policy, MIT Press, 1995.

(1984),"Commodity Prices and Money: Lessons from International Finance," American Journal of Agricultural Economics 66, no. 5, pp. 560-566.

(1995), "The Stabilizing Properties of a Nominal GNP Rule," Journal of Money, Credit and Banking 27, no. 2, May, pp. 318-334.

(2002), "Should Gold-Exporters Peg Their Currencies to Gold?" Research Study No. 29, World Gold Council, London, UK.

(2003), "A Proposed Monetary Regime for Small Commodity-Exporters: Peg the Export Price ('PEP')," International Finance (Blackwill Publ.), vol. 6, no. 1, Spring, pp. 61-88.

(2005), "Peg the Export Price Index: A Proposed Monetary Regime for Small Countries," vol. 27, no. 4, June, J. of Policy Modeling .

Frankel, Jeffrey and Gikas Hardouvelis (1985), "Commodity Prices, Money Surprises, and Fed Credibility," Journal of Money, Credit and Banking 17, no. 4 (Nov., Part I), 427-438. Reprinted in Frankel op cit.

Frankel, Jeffrey, and Ayako Saiki (2002), "A Proposal to Anchor Monetary Policy by the Price of the Export Commodity" Journal of Economic Integration, Sept., vol. 17, No. 3, pp. 417-448.

Graham, Benjamin (1937), Storage and Stability. New York: McGraw Hill.

Hall, Robert (1982), "Explorations in the Gold Standard and Related Policies for Stabilizing the Dollar," in Hall, ed., Inflation. Chicago: Univ. of Chicago Press, pp. 111-122.

Keynes, John Maynard (1938), "The Policy of Government Storage of Foodstuffs and Raw Materials," Economic Journal, September.

Kolb, Robert W. (1992), “Is Normal Backwardation Normal?” Journal of Futures Markets, 12, pp. 75-91.

Mankiw, N. Gregory, and Ricardo Reis (2003), "What Measure of Inflation Should a Central Bank Target?" in International Seminar on Macroeconomics, Journal of the European Economic Association, 1, no. 5, September, The MIT Press, Cambridge . 
Okun, Arthur (1975). "Inflation: Its Mechanics and Welfare Costs.” Brookings Papers on Economic Activity 2, pp. 351-401.

Rogoff, Kenneth (1985), "The Optimal Degree of Commitment to an Intermediate Monetary Target," Quarterly Journal of Economics 100 (November), pp. 1169-89.

Svensson, Lars (1995), "The Swedish Experience of an Inflation Target," in Inflation Targets, edited by Leo Leiderman and Lars Svensson. Centre for Economic Policy Research, London. (1999), "Inflation Targeting as a Monetary Policy Rule," Journal of Monetary Economics 43, pp. 607-654.

Svensson, Lars, and Michael Woodford (2005), “Implementing Optimal Policy through Inflation-Forecast Targeting," in Ben Bernanke and Michael Woodford, eds., The InflationTargeting Debate, University of Chicago Press, Chicago.

Truman, Edwin (2003), Inflation Targeting in the World Economy, Institute for International Economics, Washington DC.

Working, Holbrook (1949), "The Theory of Price Storage" American Economic Review, vol. 30, December, pp.1254-62.

Yang, Jian; Bessler, David, and Leatham, David (2001), “Asset Storability and Price Discovery in Commodity Futures Markets: A New Look," The Journal of Futures Markets, vol. 21, no.3, March. 


\section{Appendix I}

\section{Figure 1: US Real Commodity Prices and Real Interest Rates}

Figures $1 \mathrm{~d}$ and $1 \mathrm{e}$ (with shorter time period sample)

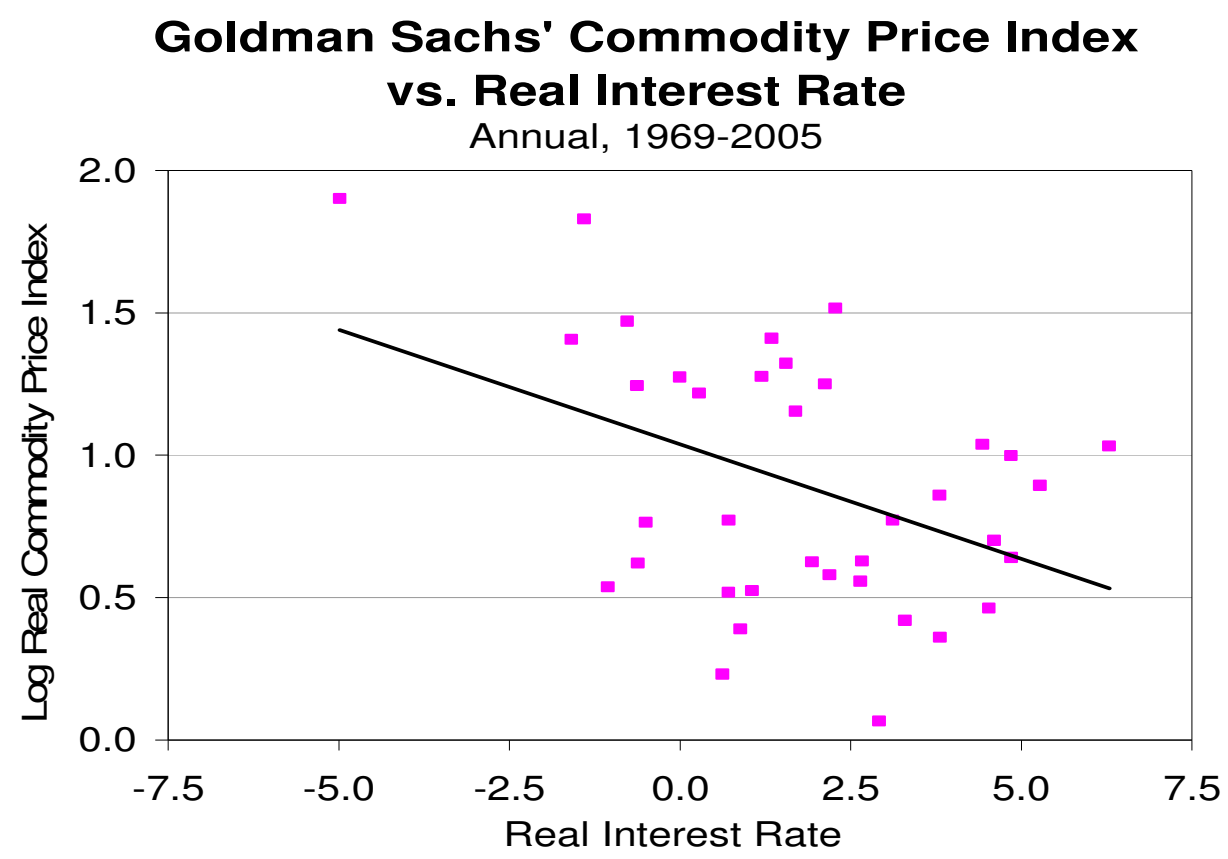

Source: Global Financial Data Inc.

Reuters Commodity Price Index vs.

Real Interest Rate

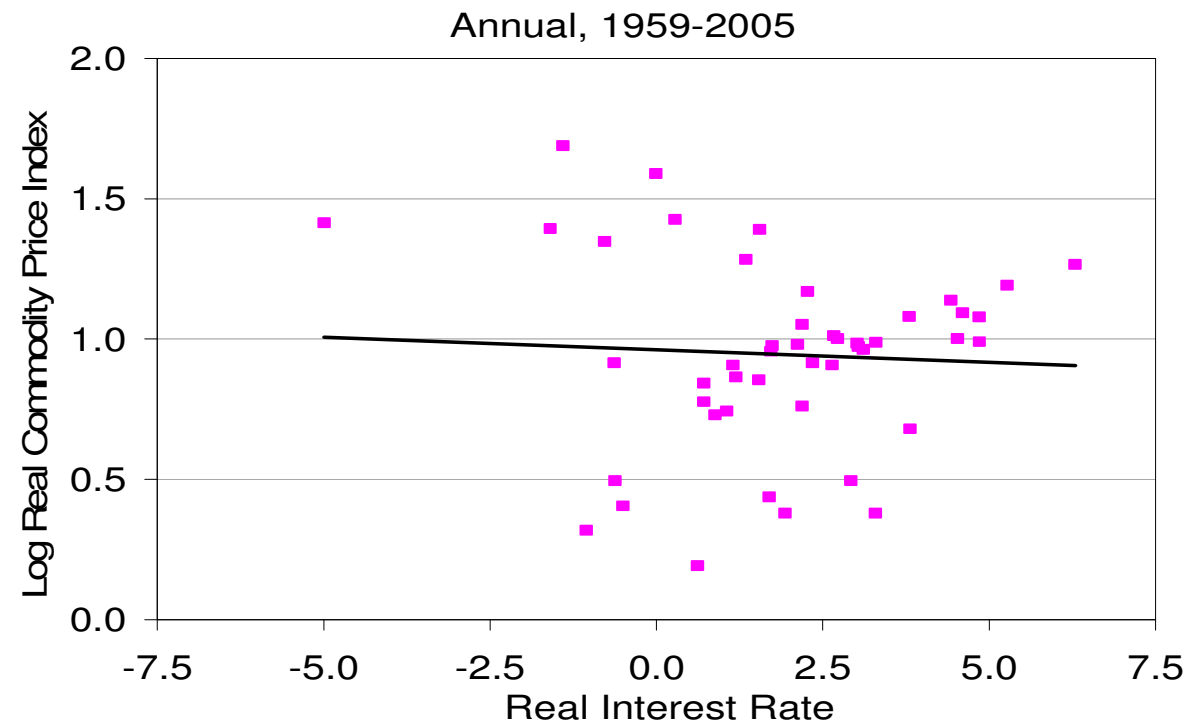

Source: Global Financial Data Inc. 
Table 1a:

Regression of log real commodity prices on real interest rates over 1950-1979.

Results by commodity indices, individual commodities and fixed-effects panel.

\begin{tabular}{|c|c|c|c|}
\hline \multicolumn{4}{|c|}{$\begin{array}{l}\text { Log Real Commodity Prices and Interest Rates } \\
\text { sample: } 1950-1979 \text { ( } 30 \text { annual observations) } \\
\text { real interest rate in \% and real commodity prices in log units }\end{array}$} \\
\hline & Coefficient & Std error & sig. $5 \%$ \\
\hline Reuters (1959-) & -0.080 & 0.023 & * \\
\hline Goldman Sachs (1969-) & -0.078 & 0.028 & * \\
\hline Dow Jones & -0.060 & 0.015 & * \\
\hline Moodys & -0.052 & 0.013 & * \\
\hline CRB & -0.044 & 0.012 & * \\
\hline \multicolumn{4}{|c|}{ COMMODITIES (by coefficient in ascending order) } \\
\hline Sugar & -0.173 & 0.040 & * \\
\hline Gold & -0.117 & 0.036 & * \\
\hline Soy bean oil & -0.093 & 0.021 & * \\
\hline Zinc & -0.090 & 0.025 & * \\
\hline Oil & -0.085 & 0.032 & * \\
\hline Corn & -0.071 & 0.017 & * \\
\hline Cocoa & -0.070 & 0.037 & \\
\hline Silver & -0.068 & 0.044 & \\
\hline Palladium & -0.067 & 0.023 & * \\
\hline Wheat & -0.061 & 0.024 & * \\
\hline Rubber & -0.058 & 0.041 & \\
\hline FIXED-EFFECTS PANEL & -0.056 & 0.006 & * \\
\hline Coffee & -0.055 & 0.028 & \\
\hline Oats & -0.053 & 0.015 & * \\
\hline Soy beans & -0.048 & 0.014 & * \\
\hline Tin & -0.048 & 0.027 & \\
\hline Lead & -0.042 & 0.018 & * \\
\hline Cotton & -0.034 & 0.025 & \\
\hline Platinum & -0.030 & 0.015 & * \\
\hline Cattle & -0.026 & 0.014 & \\
\hline Hogs & -0.020 & 0.024 & \\
\hline Nickel & -0.014 & 0.017 & \\
\hline Aluminium & 0.000 & 0.011 & \\
\hline Copper & 0.029 & 0.021 & \\
\hline
\end{tabular}


Table 1b:

Regression of log real commodity prices on real interest rates over 1980-2005.

Results by commodity indices, individual commodities and fixed-effects panel.

\begin{tabular}{|c|c|c|c|}
\hline \multicolumn{4}{|c|}{$\begin{array}{l}\text { Log Real Commodity Prices and Interest Rates } \\
\text { sample: 1980-2005 (26 annual observations) } \\
\text { real interest rate in \% and real commodity prices in log units }\end{array}$} \\
\hline & Coefficient & Std error & sig. $5 \%$ \\
\hline Moodys & 0.014 & 0.018 & \\
\hline Goldman Sachs & 0.033 & 0.030 & \\
\hline Dow Jones & 0.056 & 0.026 & * \\
\hline CRB & 0.076 & 0.026 & * \\
\hline Reuters & 0.108 & 0.024 & * \\
\hline \multicolumn{4}{|c|}{ COMMODITIES (by coefficient in ascending order) } \\
\hline Nickel & -0.036 & 0.038 & \\
\hline Palladium & 0.012 & 0.051 & \\
\hline Lead & 0.016 & 0.029 & \\
\hline Cattle & 0.020 & 0.015 & \\
\hline Sugar & 0.026 & 0.049 & \\
\hline Platinum & 0.031 & 0.029 & \\
\hline Oil & 0.039 & 0.044 & \\
\hline Zinc & 0.044 & 0.022 & * \\
\hline Aluminium & 0.049 & 0.022 & * \\
\hline Hogs & 0.061 & 0.030 & * \\
\hline Copper & 0.068 & 0.036 & \\
\hline Rubber & 0.069 & 0.038 & \\
\hline FIXED-EFFECTS PANEL & 0.072 & 0.008 & * \\
\hline Gold & 0.078 & 0.037 & * \\
\hline Soy bean oil & 0.079 & 0.031 & * \\
\hline Wheat & 0.081 & 0.034 & * \\
\hline Cotton & 0.084 & 0.030 & * \\
\hline Corn & 0.086 & 0.034 & * \\
\hline Soy beans & 0.087 & 0.032 & * \\
\hline Oats & 0.090 & 0.040 & * \\
\hline Cocoa & 0.120 & 0.039 & * \\
\hline Silver & 0.126 & 0.045 & * \\
\hline Tin & 0.163 & 0.045 & * \\
\hline Coffee & 0.253 & 0.036 & * \\
\hline
\end{tabular}




\section{Appendix 2: \\ Relationship between de-trended oil inventories and interest rates}

We have used various methods to detrend the inventories series: linear, quadratic and Hodrick-Prescott Filter. To maximize smoothness, the largest possible smoothness parameter was chosen for the HP filter (1 billion). At this level of smoothness, the HP filter series resembled those generated using the linear or quadratic method.

Graphs show the linear and quadratic detrended series:

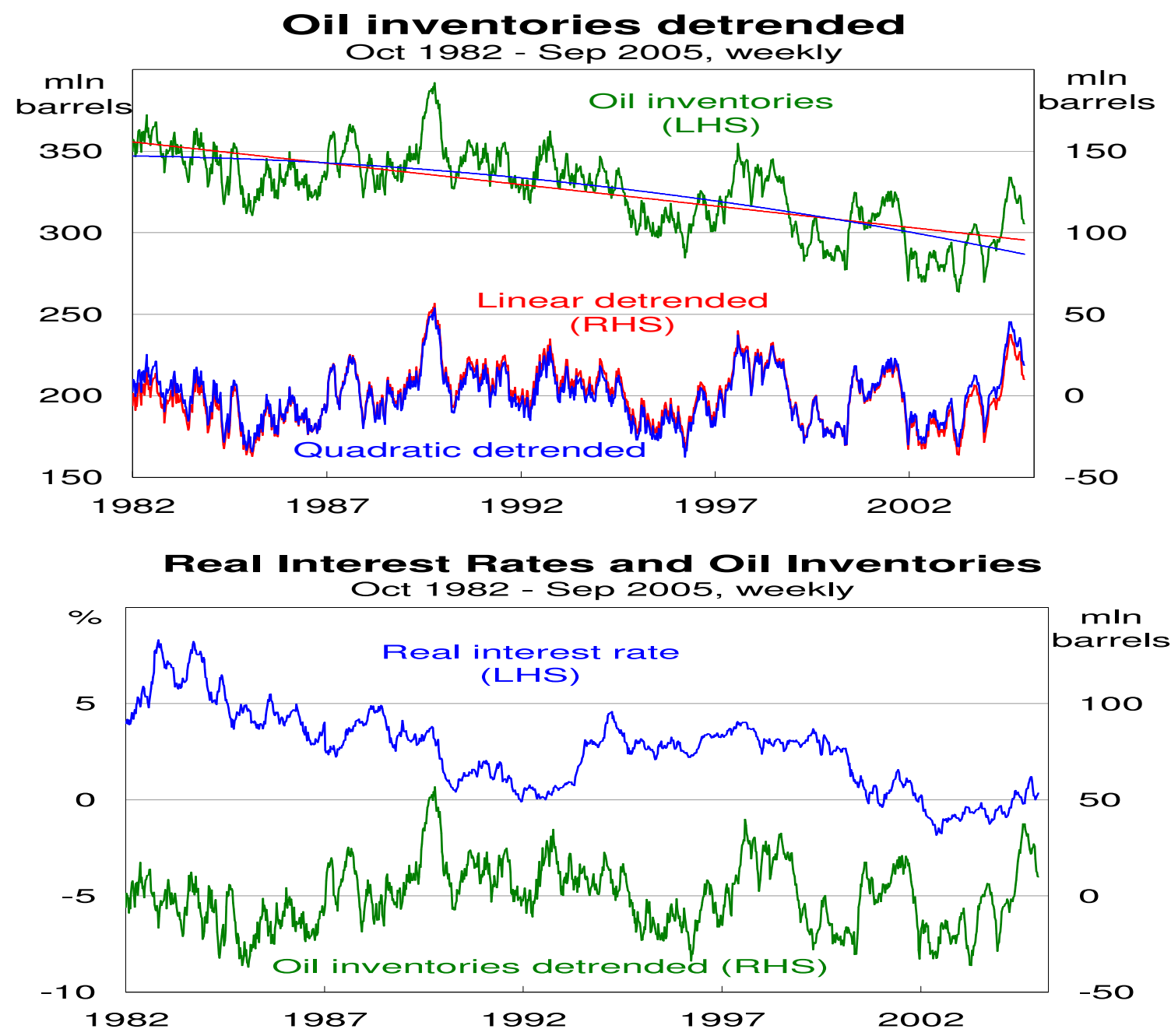

\section{Regressions}

Six regressions have been estimated to explore this relationship.

$>$ In regression 1 , there is no detrending.

$>$ In regressions $2 \& 3$, linear $(\alpha \mathrm{t})$ or quadratic trends $\left(\alpha \mathrm{t}+\beta \mathrm{t}^{2}\right)$ are included as extra regressors.

$>$ Regressions $4-6$ use a two step procedure, first detrending the inventories series and then estimating the relationship. 
When the linear detrending method is used, there is a significant negative relationship between the real rate and inventories. However, this result is not robust to the use of alternative detrending methods if one fails to control for other important influences on inventory demand.

\section{Table 4: Relationship between oil inventories and interest rates}

\begin{tabular}{llccc} 
Regressand & Regressors & $\begin{array}{c}\text { Real rate } \\
\text { coefficient }\end{array}$ & $\begin{array}{c}\text { Standard } \\
\text { error }\end{array}$ & $\begin{array}{c}\text { Sig. at } \\
\mathbf{1 0 \%}\end{array}$ \\
\hline 1. Inventories & Real rate & 5.96 & 0.29 & $*$ \\
2. Inventories & Real rate \& linear trend & -0.69 & 0.35 & $*$ \\
3. Inventories & Real rate \& quadratic trend & -0.36 & 0.35 & \\
4. Linear detrended inventories & Real rate & -0.31 & 0.23 \\
5. Quadratic detrended inventories & Real rate & -0.17 & 0.23 \\
6. HP detrended inventories & Real rate & 0.04 & 0.22
\end{tabular}

\section{Appendix 3: Relationship between Detrended Oil Inventories and Real Interest Rates Controlling for Additional Regressors}

This appendix estimates an inventory equation controlling for three regressors, beyond the interest rate: risk in oil exporters, industrial activity in importing countries, and the spot-futures spread.

\section{Risk in oil exporting countries (used as a measure of risk of supply disruptions)}

We obtained monthly data from the PRS Group on the "composite risk" for each of the top 12 oil exporting countries. The composite risk ratings cover political risk, economic risk and financial risk. We have constructed a single measure for the top 12 oil exporters by arithmetically weighting the composite risk rating for each country by the country's share of world oil exports in 2003 and 2004. The countries included are (in descending order of importance): Saudi Arabia, Russia/USSR, Norway, Iran, Venezuela, UAE, Kuwait, Nigeria, Mexico, Algeria, Libya and Iraq. A fall in the index represents an increase in risk. Since the series trends up over time, we have made the series stationary by detrending or differencing. When differencing, we use a relatively tight 12 week change so there is not a large phase shift.

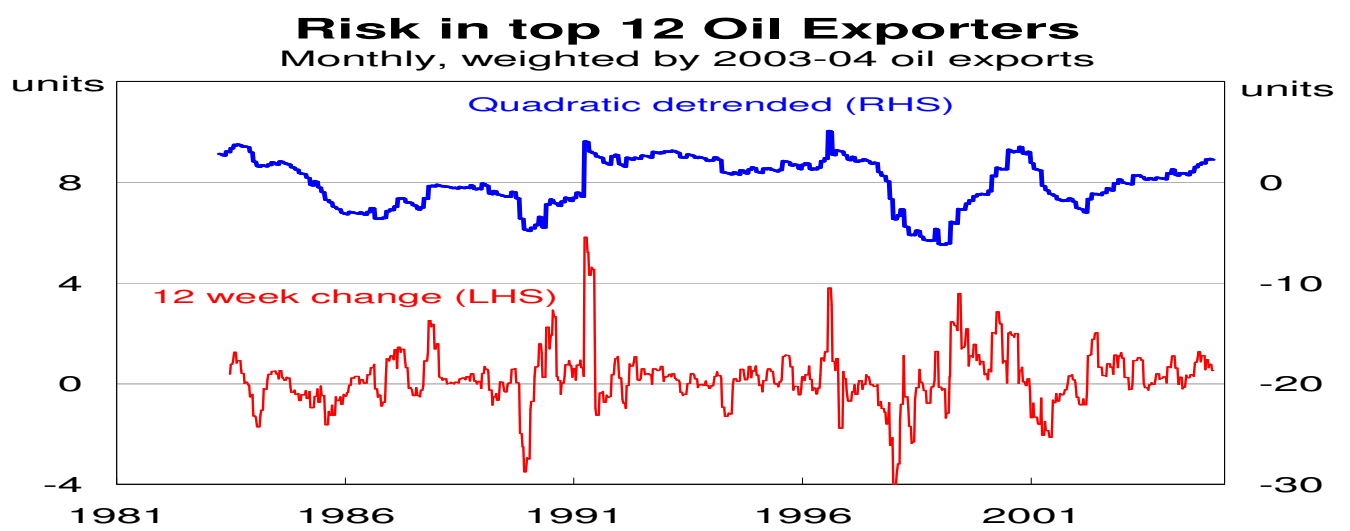




\section{Industrial Countries' Industrial Production (a measure of changes in demand)}

A monthly series of Industrial Production in Industrial Countries has been obtained from the IMF IFS database. Since the data were not seasonally adjusted and displayed a strong seasonal pattern, we seasonally adjusted the data using the X-12-ARIMA algorithm provided in the software Demetra. The series trended up, so detrending or differencing have been used to make the series stationary:

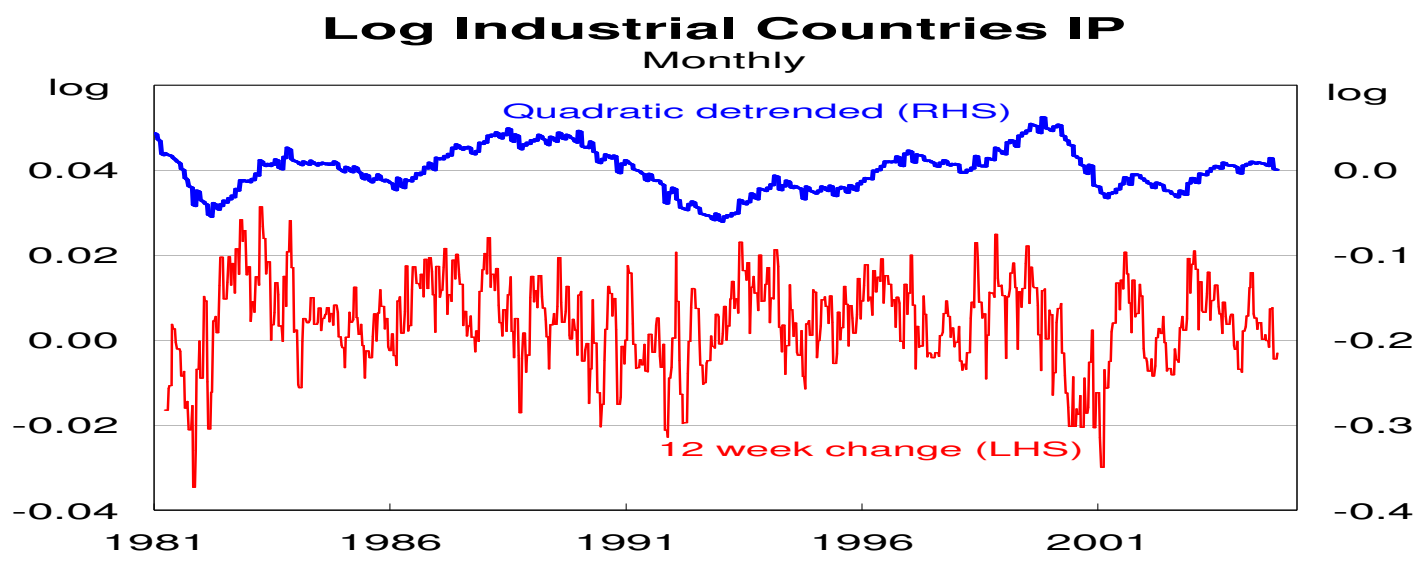

\section{Spot-futures price spread}

The spot - futures price spread has been calculated by taking the percentage difference between the first futures contract (which is close to the spot rate) and the third futures contract $(s+i-f)$, adjusting for the three month Treasury rate over the two month period between the contracts (the maturity is not matched perfectly). There is quite a high correlation between this spread and movements in US oil inventories:

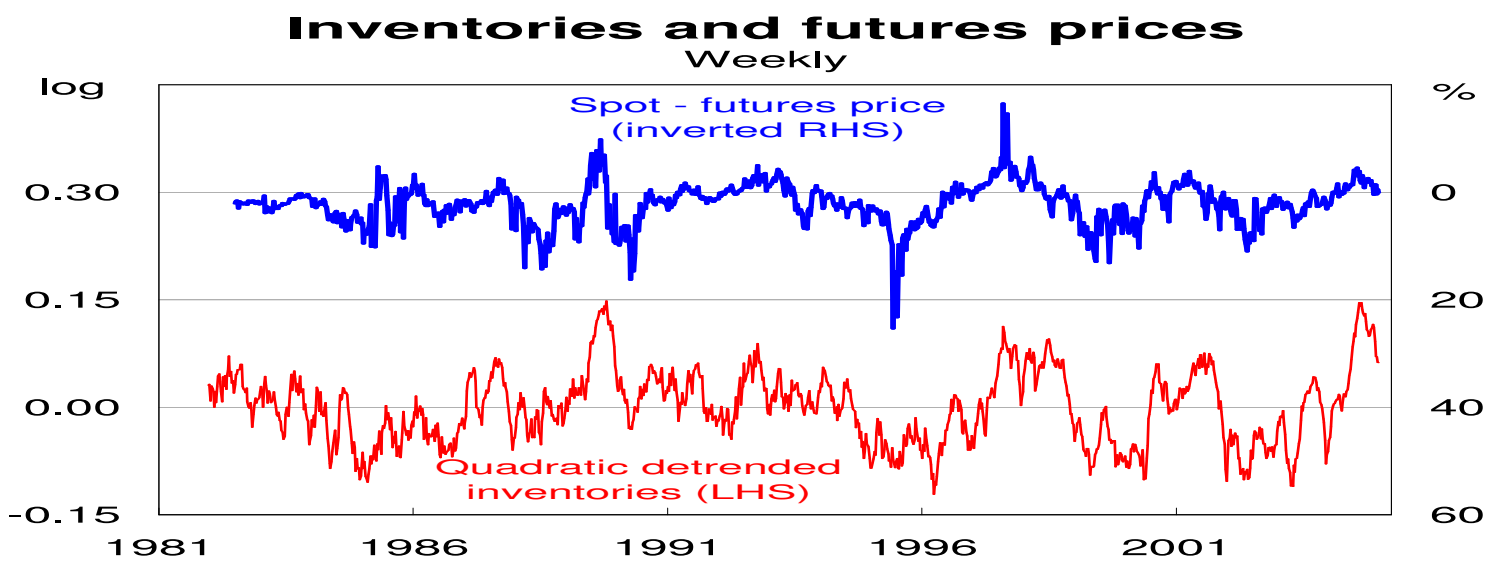




\section{Regression results}

The relationship between weekly oil inventories and real interest rates is estimated controlling for the three regressors described above. When included individually, the spot-futures price spread is significant with the expected sign (when the spot price rises relative to the futures price, oil inventories fall). The 12-week change in oil exporter risk is also significant with the expected sign (a negative change in the risk rating leads to an increase in oil inventories). However, Industrial production is not significant. The real interest rate coefficient is negative in all these regressions, but is not significant.

When all the regressors are included simultaneously (either in levels OR in changes), the spot-futures spread and risk are both significant with the expected sign. The real rate coefficient is negative and significant. When lagged inventories are added, the real rate coefficient is no longer significant. When the spot-futures spread is assumed to be endogenous and IP and risk are used as instruments, the real rate coefficient is not significant.

Table 5a: Relationship between inventories and interest rates -- Weekly data (1114-1190 observations depending on data availability)

Non-stationary variables detrended by including quadratic terms in each regression

\begin{tabular}{|c|c|c|c|c|c|c|c|}
\hline & Real rate & $\begin{array}{l}\text { Spot- } \\
\text { futures }\end{array}$ & IP & $\Delta \mathrm{IP}$ & Risk & $\Delta$ risk & $\begin{array}{c}\text { Inventories } \\
(\mathrm{t}-1)\end{array}$ \\
\hline \multirow{2}{*}{ Real rate only } & -0.064 & & & & & & \\
\hline & 0.097 & & & & & & \\
\hline \multirow{2}{*}{ Spot-futures spread } & -0.093 & $-0.760 *$ & & & & & \\
\hline & 0.077 & 0.039 & & & & & \\
\hline \multirow{2}{*}{ IP } & -0.057 & & 0.008 & & & & \\
\hline & 0.101 & & 0.059 & & & & \\
\hline \multirow{2}{*}{12 week $\Delta$ IP } & -0.014 & & & -0.178 & & & \\
\hline & 0.103 & & & 0.136 & & & \\
\hline \multirow{2}{*}{ oil exporter risk } & -0.095 & & & & 0.000 & & \\
\hline & 0.103 & & & & 0.001 & & \\
\hline \multirow{2}{*}{12 week $\Delta$ oil exporter risk } & -0.192 & & & & & $-0.009 *$ & \\
\hline & 0.100 & & & & & 0.001 & \\
\hline \multirow{2}{*}{ Spot-futures, IP, risk } & $-0.394 *$ & $-0.821 *$ & $0.397 *$ & & $-0.002 *$ & & \\
\hline & 0.089 & 0.041 & 0.062 & & 0.001 & & \\
\hline \multirow{2}{*}{$\begin{array}{l}\text { Spot-futures, IP, risk and lagged } \\
\text { inventories }\end{array}$} & -0.056 & $-0.079 *$ & $0.052 *$ & & 0.000 & & $0.931 *$ \\
\hline & 0.032 & 0.013 & 0.020 & & 0.000 & & 0.009 \\
\hline \multirow{2}{*}{ Spot-futures, $\Delta$ IP, $\Delta$ risk } & $-0.211 *$ & $-0.727 *$ & & 0.131 & & $-0.005 *$ & \\
\hline & 0.085 & 0.040 & & 0.126 & & 0.001 & \\
\hline \multirow{2}{*}{$\begin{array}{l}\text { Spot-futures, } \Delta \text { IP, } \Delta \text { risk and } \\
\text { lagged inventories }\end{array}$} & -0.017 & $-0.071 *$ & & 0.009 & & 0.000 & $0.937 *$ \\
\hline & 0.032 & 0.012 & & 0.045 & & 0.000 & 0.009 \\
\hline \multicolumn{8}{|l|}{ Instrumental Variables } \\
\hline \multirow{2}{*}{$\begin{array}{l}\text { Spot-futures; instruments: IP and } \\
\text { risk }\end{array}$} & -0.068 & 0.343 & & & & & \\
\hline & 0.124 & 0.178 & & & & & \\
\hline \multirow{2}{*}{$\begin{array}{l}\text { Spot-futures; instruments: } \Delta \text { IP } \\
\text { and } \Delta \text { risk }\end{array}$} & -0.159 & $-1.313 *$ & & & & & \\
\hline & 0.102 & 0.212 & & & & & \\
\hline
\end{tabular}

Asterisks indicate significance at the $5 \%$ level of significance. 
The results are reasonably similar when the data are detrended by including quadratic terms in each regression or through a first stage regression of each nonstationary regressor on a quadratic trend, with the residuals used in the second stage regression where inventories is the regressand.

Table 5b: Relationship between inventories and interest rates -- Weekly data Inventories, IP and oil exporter risk detrended using first stage regressions with quadratic trends

\begin{tabular}{|c|c|c|c|c|c|c|c|}
\hline & Real rate & $\begin{array}{l}\text { Spot- } \\
\text { futures }\end{array}$ & IP & $\Delta$ IP & Risk & $\Delta$ risk & $\begin{array}{l}\text { Inventories } \\
(\mathrm{t}-1)\end{array}$ \\
\hline \multirow{2}{*}{ Real rate only } & -0.031 & & & & & & \\
\hline & 0.065 & & & & & & \\
\hline \multirow{2}{*}{ Spot-futures spread } & 0.021 & $-0.754 *$ & & & & & \\
\hline & 0.053 & 0.039 & & & & & \\
\hline \multirow{2}{*}{ IP } & 0.011 & & -0.003 & & & & \\
\hline & 0.065 & & 0.058 & & & & \\
\hline \multirow{2}{*}{12 week $\Delta$ IP } & 0.043 & & & -0.200 & & & \\
\hline & 0.070 & & & 0.133 & & & \\
\hline \multirow{2}{*}{ oil exporter risk } & $-0.154 *$ & & & & 0.000 & & \\
\hline & 0.076 & & & & 0.001 & & \\
\hline \multirow{2}{*}{12 week $\Delta$ oil exporter risk } & $-0.226 *$ & & & & & $-0.009 *$ & \\
\hline & 0.077 & & & & & 0.001 & \\
\hline \multirow{2}{*}{ Spot-futures, IP, risk } & $-0.131 *$ & $-0.806 *$ & $0.304 *$ & & $-0.002 *$ & & \\
\hline & 0.067 & 0.042 & 0.062 & & 0.001 & & \\
\hline \multirow{2}{*}{$\begin{array}{l}\text { Spot-futures, IP, risk and lagged } \\
\text { inventories }\end{array}$} & -0.027 & $-0.076 *$ & $0.044 *$ & & 0.000 & & $0.933 *$ \\
\hline & 0.023 & 0.013 & 0.019 & & 0.000 & & 0.009 \\
\hline \multirow{2}{*}{ Spot-futures, $\Delta$ IP, $\Delta$ risk } & -0.066 & $-0.723 *$ & & 0.089 & & $-0.005 *$ & \\
\hline & 0.065 & 0.041 & & 0.127 & & 0.001 & \\
\hline \multirow{2}{*}{$\begin{array}{l}\text { Spot-futures, } \Delta \text { IP, } \Delta \text { risk and } \\
\text { lagged inventories }\end{array}$} & -0.003 & $-0.070 *$ & & 0.006 & & 0.000 & $0.937 *$ \\
\hline & 0.024 & 0.012 & & 0.044 & & 0.000 & 0.009 \\
\hline \multicolumn{8}{|l|}{ Instrumental Variables } \\
\hline \multirow{2}{*}{$\begin{array}{l}\text { Spot-futures; instruments: IP and } \\
\text { risk }\end{array}$} & -0.145 & 0.282 & & & & & \\
\hline & 0.086 & 0.179 & & & & & \\
\hline \multirow{2}{*}{$\begin{array}{l}\text { Spot-futures; instruments: } \Delta \text { IP } \\
\text { and } \Delta \text { risk }\end{array}$} & 0.076 & $-1.368 *$ & & & & & \\
\hline & 0.072 & 0.231 & & & & & \\
\hline
\end{tabular}




\section{Appendix 4 : Relationship between Agricultural Inventories and Real Interest Rates, using Detrended Inventories}

Annual inventories data were obtained from the US Department of Agriculture for 12 agricultural commodities. For comparative purposes, we also include results using a series for petroleum inventories from the Energy Department. To make the results easier to compare across commodities, we logged the inventories series, so the coefficients are semi-elasticities. Quarterly inventories data are available for some commodities, but the seasonal patterns are extremely strong, so we converted all the commodities to a common annual frequency.

We estimated five regressions to explore this relationship for each commodity:

$>$ In regression 1 , there is no detrending.

$>$ In regressions $2 \& 3$, linear $(\alpha \mathrm{t})$ or quadratic trends $\left(\alpha t+\beta \mathrm{t}^{2}\right)$ are included as extra regressors.

$>$ Regressions 4 \& 5 use a two step procedure, first detrending the inventories series and then estimating the relationship.

The data suggest no systematic negative relationship between real interest rates and agricultural inventories. The different specifications do not appear to have a significant effect on the results. The relationship has also been estimated for the fixed effects panel of the nine commodities with data available from 1950-2004. This sample is broken in 1982 to test for any effect from the change in monetary policy regime. The results suggest there is a spurious positive relationship between interest rates and inventories. The results for agricultural inventories are not to be taken too seriously as we were unable to control for risk or other important variables. 
Table 6: Relationship between agricultural inventories \& interest rates --Annual data

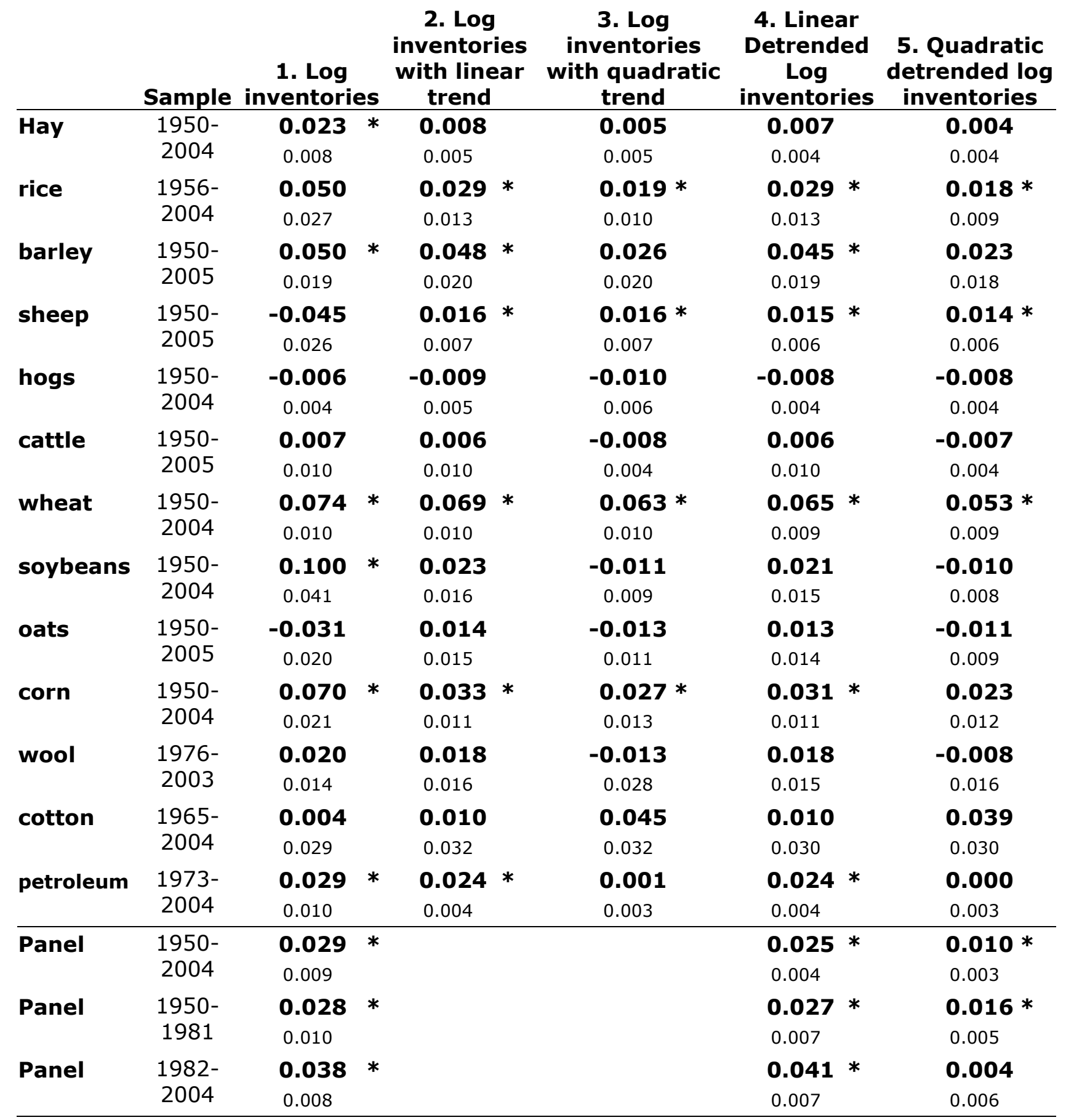

Asterisks indicate significance at the $5 \%$ level of significance. 